$11-18-2021$

\title{
Development and Implementation of an Opioid Risk-Reduction Strategy
}

\author{
Heather Darmetko \\ University of St. Augustine for Health Sciences, h.darmetko@usa.edu
}

DOI: https://doi.org/10.46409/sr.SIQK4480

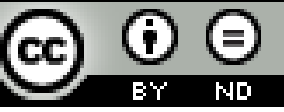

This work is licensed under a Creative Commons Attribution-No Derivative Works 4.0 License.

Follow this and additional works at: https://soar.usa.edu/scholprojects

Part of the Nursing Commons, and the Patient Safety Commons

\section{Recommended Citation}

Darmetko, H. (2021). Development and Implementation of an Opioid Risk-Reduction Strategy. [Doctoral project, University of St Augustine for Health Sciences]. SOAR @ USA: Student Scholarly Projects Collection. https://doi.org/10.46409/sr.SIQK4480 
Development and Implementation of an Opioid Risk-Reduction Strategy

Heather Darmetko, MSN, FNP-C

School of Nursing, University of St. Augustine for Health Sciences

This Manuscript Partially Fulfills the Requirements for the

Doctor of Nursing Practice Program and is Approved by:

Dr. Sarah Cartwright, DNP, MSN-PH, BAM, RN-BC, CAPA, FASPAN

Dr. Greg Hites, DNP, FNP-BC

Date of Final Approval: November 18, 2021 


\section{University of St. Augustine for Health Sciences \\ DNP Scholarly Project \\ Signature Form}

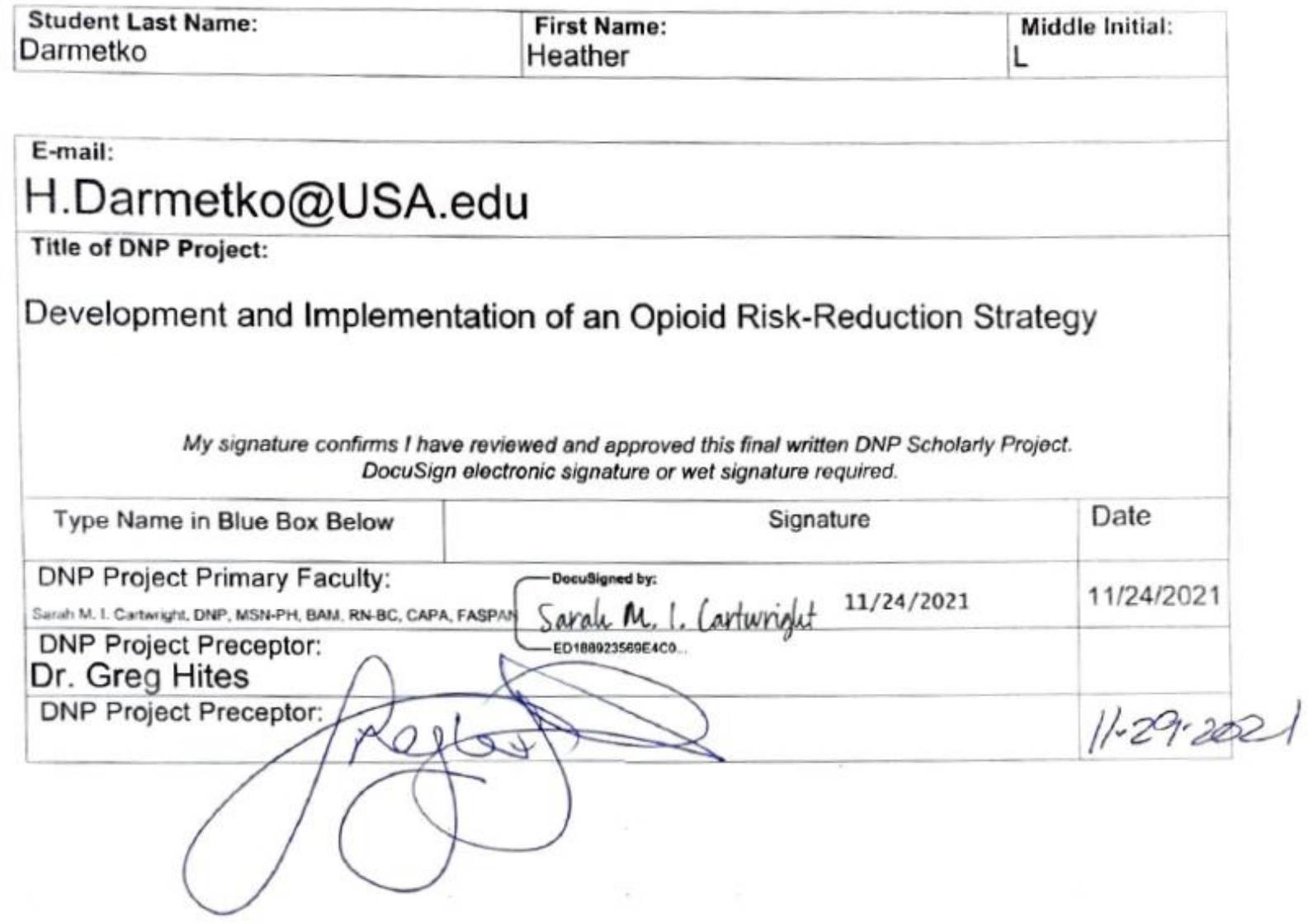




\begin{abstract}
Practice Problem: Accidental overdose is a continued concern for those who are prescribed opioids, and it is essential that healthcare members intensify prevention and response measures in order to prevent death or misuse from this medication.
\end{abstract}

PICOT: The PICOT question that guided this project was: "In adult patients at an outpatient chronic pain management clinic (P), how does development and implementation of a safe opioid risk-reduction office policy (I), compared to usual practice (C), improve patient rates of naloxone availability and health literacy $(\mathrm{O})$ over eight weeks $(\mathrm{T})$ ?”

Evidence: The CDC's Guideline for Prescribing Opioids for Chronic Pain, the Surgeon General's Advisory on Naloxone and Opioid Overdose, and the U.S Department of Health and Human Services website were used to gather evidence-based components for information and practice changes.

Intervention: This project created a safe opioid risk-reduction strategy in the form of a new office protocol that ensured naloxone was received with instruction on what to do in the event of an overdose or life-threatening respiratory reaction to opioids and other safety information. The providers assessed the change in knowledge by using the teach back method.

Outcome: The results showed improvement in the availability of naloxone as a reversal agent as well as increased understanding of safe opioid storage, disposal, and drug interactions.

Conclusion: The manuscript reports barriers, successes, and challenges discovered during the project. The recommendations can be applied to other outpatient clinic sites to enhance the safety of all patients who manage their chronic pain with the use of prescription opioids. 


\section{Development and Implementation of a Safe Opioid Risk-Reduction Strategy}

Over the last several years, accidental overdose has become a common cause of preventable deaths. (Martino et al., 2019). This is a major public health issue. Unfortunately, both providers and the public lack understanding of the serious risks associated with opioid use (Agency for Healthcare Research and Quality, 2019).

The Centers for Disease Control and Prevention (CDC) identified patients who had a greater risk of prescription opioid overdose as "those who were prescribed high daily dosages of opioids for chronic pain, who concurrently used benzodiazepines with opioids, and/or had a history of a substance use disorder" (2019, para. 11). Adults with limited health literacy have difficulty managing their chronic conditions, which leads to greater hospitalization rates and higher healthcare expenses (Ylitalo et al., 2018). Naloxone hydrochloride is a competitive opioid antagonist that binds to the mu receptors in the body (CDC, 2019). This medication can rapidly "reverse the effects of opioids including those associated with overdose such as respiratory depression" and increased access to naloxone can reduce overdose death by $35-50 \%$ (National Institutes of Health, 2017, U.S Department of Health and Human Services [HHS], 2018a, p.1). Regrettably, this life-saving medication is not always available during situations when it is needed the most (CDC, 2019).

This evidenced-based project (EBP) created a safe opioid risk-reduction strategy in the form of a new office protocol designed to ensure all patients using prescription opioids received a prescription for naloxone and instruction on what to do in the event of an overdose or lifethreatening respiratory reaction to opioids (Next Harm Reduction, Inc., 2020). For those who could not afford the medication, a shipment of Narcan was provided to them through a collaboration with Next Harm Reduction, Inc. (2020). The CDC and The American Society of 
Regional Anesthesia and Pain Medicine (ASRA) recommended patient handouts were also used to increase understanding of the potential dangers of opioids and reviewed the safe storage, disposal, tapering medications, and potential interactions with other substances (ASRA, n.d.; HHS, 2018b). This project reduced the risk of accidental overdose and ensured the safe use of prescription opioid medication.

\section{Significance of the Practice Problem}

During the last 15 years overdoses from synthetic and non-synthetic opioid use have increased fourfold in the United States (Frieden \& Houry, 2016). During the years 1999 to 2017, nearly 400,000 people died from drug overdoses involving prescription or illicit opioids (CDC, 2020). Nearly 40 percent of those deaths were a direct result of prescription opioid overuse or misuse. Neville and Foley (2020) reported the total of yearly opioid related deaths outnumbered the annual mortality rates caused by recent wars, motor vehicle accidents, gun violence, and HIV combined. The authors argued these deaths were in part a result of increased efforts to improve pain management, especially since the inception of pain as a fifth vital sign in 1996. Some have termed this "the biggest public health epidemic of a generation" (Florence et al., 2021, p. 218).

The overdose crisis affects society on all levels. A considerable economic burden has been triggered by the rise in opioid related morbidity and mortality rates. One estimation is that the total cost of prescription opioid misuse in the United States is close to 79 billion dollars a year (CDC, 2019). The combined costs of opioid use disorder and fatal opioid overdose was estimated to be as high as one trillion dollars in the year 2017 (Florence et al., 2021). These losses are associated with issues including "premature mortality, criminal justice, childcare and family assistance, lost productivity, and healthcare services" (Neville \& Foley, 2020, p. 10). 
Most of the economic burden, however, can be attributed to loss of life and reduced quality of living (Florence et al., 2021).

The EBP change clinic is in an urban environment in Southwestern Pennsylvania. On a statewide level, the prevalence of opioid use disorder was 5.54 per 1,000 commercially insured residents which totaled almost 40,000 persons in 2016 (Davenport et al., 2019). These figures accounted for an increased cost of " $\$ 16,277$ per patient and totals nearly 650 million dollars in yearly costs" (p. 71). Data from a 2020 analysis indicated this area of Pennsylvania was below the state average for median household income, median house value, and house age (City Data, n.d.). The renting percentage and length of stay after moving were also above state average. The percentage of this population with a bachelor's degree or higher and the number of college students was below state average. The website states that the percentage of those with a high school degree or higher was $86.8 \%$, a bachelor's degree or higher was $12.9 \%$, and those with a graduate or professional degree was $3.1 \%$. The unemployment rate was $7.8 \%$, which was slightly higher than the state average of $6.1 \%$.

To curb the increase in prescription opioid overdose rates, several harm reduction strategies, including use of naloxone for home rescue have been recommended (Dowell et al., 2016; Frieden \& Houry, 2016; Wyse et al., 2018). However, at the clinic where this EBP project was implemented, even though providers were encouraged to prescribe naloxone, usually in the form of Narcan, many patients still were not receiving this potentially lifesaving medication. Identified potential barriers to prescribing naloxone include "stigma toward opioid users, fear of negative consequences such as increased drug use, time constraints, billing and reimbursement complications, low self confidence in having discussions with patients, and lack of clinician education" (Martino et al., 2019, p. 69). There was no formal office protocol or tracking method 
to make sure patients understood the importance of naloxone, how to administer it, or safe handling of their opioid prescriptions (G. Hites, personal communication, January 11, 2021).

\section{PICOT Question}

The PICOT question: "In adult patients at an outpatient chronic pain management clinic (P), how does development and implementation of a safe opioid risk-reduction office policy (I), compared to usual practice $(\mathrm{C})$, improve patient rates of naloxone availability and health literacy (O) over eight weeks (T)?” was created to find the best evidence-based practice literature available that would support formulation of the project (Echevarria \& Walker, 2014).

For this project, the population targeted was adult patients attending an outpatient interventional pain management clinic, that were aged between eighteen and ninety-nine years with no defined race or ethnicity. The individual conditions varied, but all participants had a diagnosis of pain lasting greater than three months and were prescribed opioids to help manage their chronic pain.

The intervention guided the development and implementation of a safe opioid office policy. The CDC's Guideline for Prescribing Opioids for Chronic Pain, the Surgeon General's Advisory on Naloxone and Opioid Overdose, and the U.S Department of Health and Human Services website were used to gather evidence-based components for the information and practice changes (ASRA, n.d.; Frieden \& Houry, 2016; HHS, 2017, 2018b). The carefully chosen resources were those designed for chronic pain patients regardless of the office settings in which they presented.

The comparison to usual practice was measured at baseline and post implementation through the provider checklist, the prescription drug monitoring program (PDMP), and the teachback method. The data evaluations took place in two groups, at baseline and at the four week 
follow up visit. The teach-back method is an "evidence-based, patient-centered intervention that promotes health literacy, patient engagement and adherence, safety, and quality, using a universal precaution approach" (Denault et al., 2019, para. 4).

\section{Evidence-Based Practice Framework and Change Theory}

This section introduces the framework and change theory models that guided the project development. Specifically, the Johns Hopkins Nursing Evidence-Based Practice (JHNEBP) model and Lewin's theory of change were utilized.

\section{Framework}

To ensure the appropriate research findings and best practices for this EBP change the JHNEBP framework was followed (Dang \& Dearholt, 2017). This structure employed a threestep process called "PET: practice question, evidence, and translation" (see Appendix A). The practice question stage consisted of the initial team development, definition of the practice problem, and finally, identification and meeting with stakeholders and leadership members. In the evidence stage, quality literature was collected and appraised to determine recommendations for the project proposal. During the translation stage, synthesized data was funneled into the final action plan which defined the implementation, evaluation, and dissemination phases of the EBP project.

\section{Change Theory}

To facilitate alterations in behaviors, it was first important to understand the mechanisms behind the process of change (Lewin, 1951). Lewin's theory of change was used to guide the desired improvements in self-care behaviors of the patient and the providers during the EBP change project. Identifying the opposing forces that encourage or hinder change increased the likelihood of success and sustainability. The terms unfreeze, change, and refreeze are 
characteristics of Lewin's three-step model reviewed in Figure 1. During this project, the participant was initially prompted to alter their customary process to overcome their current behavior (unfreeze). This allowed them to view their typical actions from a different perspective and to realize the desired transformation (change). Finally, the changes were consistently implemented, and this behavior became the "new normal" (refreeze). The process concluded with the integration of the project opioid safety policy components into the standard routine of the organization for all practice locations in Pennsylvania.

\section{Evidence Search Strategy}

To ensure a comprehensive search for strong evidence, relevant literature was initially identified through an electronic search of databases. The search included the following subject terms: "chronic pain management," and "opioid." This was further investigated with the expander terms: "safety practices," "naloxone," and self-care behaviors." Databases searched were: The Cumulative Index to Nursing and Allied Health Literature via smart text searching, Joanna Briggs Institute EBP, Wolters Kluwer OVID, and Science Direct. Additionally, a thorough search was made via Google Scholar and Cochrane PICO search engines. This generated 2,673 articles of possible interest. Duplicate articles were removed and then narrowed by application of inclusion and exclusion criteria to final number of 14 .

\section{Evidence Search Results}

The following inclusion criteria were applied to the initial 2,673 literature search results: (1) adult (<18 years of age), (2) articles published within the last five years, (3) United States studies, and (4) outpatient setting. This left 362 articles remaining. Articles were then further eliminated based upon the following exclusion criteria (1) non-English language, (2) non-opioid management, (3) cancer or palliative care, and (4) secondary sources. Peer-reviewed sources 
chosen were comprised of books, journal articles, published papers and grey literature. Limiters were added that include "patient safety," and "education." These steps yielded 37 articles. Potential literature was further narrowed by a critical review of abstracts and subject matter was examined for relevancy. This thorough review ensured the article chosen discussed safety practices related to chronic pain patients who were prescribed opioids, and that the research information was appropriate to the EBP change process.

A total of fourteen articles were selected for the literature review, as shown in Figure 2. The collection included research, systematic reviews, and best practice guidelines. Of the total, five focused on opioid safety and/or naloxone prescriptions, three related to personal or organizational health literacy. See articles in Appendix A: Primary Research Review. Two systematic reviews of literature, listed in Appendix B, related to improved self-care capability. Four best practice articles supported the use of opioid risk reduction tools, such as those included in the practice policy for this EBP change and are shown in Appendix C: Consensus Statement and Guidelines. The underlying goal of increased safe opioid use was evident in each article.

The readings obtained were evaluated and labeled by level and quality using the JHNEBP model (Dang \& Dearholt, 2017, Appendix D). As shown in Table 1, all the articles were rated as I through $\mathrm{V}$ evidence levels and determined to have no less than an A/B rating with the majority (71\%) categorized as high quality- A ranked sources. Therefore, these resources were determined to be suitable valid research materials that supported the EBP project changes.

\section{Themes with Practice Recommendations}

The practice recommendation themes revealed from the final search results are further examined in this section. Project participants, practice settings, naloxone use, education, and barriers were analyzed in depth to determine final practice proposals. 


\section{Subjects}

All literature study subjects were either adult patients receiving medications classified as opioids for the purpose of reduction in chronic pain, or practitioners (physicians, pharmacists, nurse practitioners, and physician assistants) who prescribed opioids and/or educated recipients on naloxone (Martino et al., 2019; Wyse et al., 2018). Article summaries are provided in Appendices A and B.

Several studies were conducted at the Department of Veterans Affairs (VA) and the population was noted to be predominately Caucasian males (Seal et al., 2019; Tiffany et al., 2015). There were concerns that these results provided an overrepresentation of this demographic group. However, since this group tends to be most affected by opioid overdose, as evidenced by Figure 3 and Table 2, the results were determined to be valid. Veterans are part of the population of patients seen at the EBP change project location which also makes inclusion of these study results appropriate (G. Hites, personal communication, February 25, 2021). The study periods ranged from four to 52 weeks in duration.

\section{Practice Setting}

All practice study sites were in outpatient facilities except for one meta-analysis and one research study (Devries et al., 2017; Kadakia et al., 2020). However, all data were applicable to this EBP change project. It is not necessary to specifically link the impact of opioid-related education provided by the healthcare provider to a specific setting (Kadakia et al., 2020). Overall, overdose education and naloxone distribution programs were found to be successful regardless of the practice location (Devries et al., 2017). For this project, therefore, the distribution of educational materials and practice guidelines did not require adjustments based on the project practice specialty or setting. 


\section{Naloxone}

Several high-quality studies or practice recommendations focused specifically upon the reversal agent naloxone as a stand-alone intervention or in conjunction with an overall safety plan (Devries et al., 2017; HHS, 2018a; Jones et al., 2019; Martino et al., 2019; Seal et al., 2019; Tiffany et al., 2015). All outcomes showed strong support for increased provider prescribing habits, improved access to supply, and greater patient knowledge of this medication. Intranasal use, as opposed to intramuscular injection, was identified as the preferred delivery method. This was based on patient preference, willingness to administer, safety measures (such as reduced likelihood for needle stick injuries) and ease of use. The brand name medication, Narcan, was the most prescribed and used form of naloxone.

\section{Education}

Every piece of literature mentioned the impact that education had on reducing opioid risk, including overdose. Prescription counseling and instruction had a "positive impact on medication adherence and health outcomes" (Kadakia et al., 2020, p. e32). Several studies utilized targeted educational methods to increase patient knowledge (Devries et al., 2017; Highland et al., 2020; Kadakia et al., 2020; Seal et al., 2019). Individual learning styles have become increasingly dependent on digital technologies so microlearning was noted to be an effective method that improved health literacy (Wang et al., 2020). Enhanced clinician knowledge of risk reduction strategies also decreased the potential harm of opioid use for the chronic pain patient (Ducoffe et al., 2016; HHS, 2018b; Jones et al., 2019; Marszalek et al., 2020; Martino et al., 2019; Wyse et al., 2018). Comprehension abilities were indicated by the results of patient health literacy evaluations (Tiffany et al., 2015; Wang et al., 2020; Ziadni et al., 2018). The most effective delivery methods were video and written education at a third-grade level distributed in a 
collaborative manner (Devries et al., 2017; Frieden \& Houry, 2016; Kadakia et al., 2020; Seal et al., 2019).

From the provider perspective, tools found to reduce the risk of opioid harm included urine drug tests, state prescription monitoring programs, depression and abuse potential screening, discussions about medication interactions, safe storage and disposal, and patient access to an opioid reversal agent in the event of an overdose.

\section{Barriers}

Several obstacles to harm reduction health literacy were highlighted in the available literature. For example, women were noted to have greater difficulty with self-care than men and patients from low-income populations were less likely to be fully educated on the dangers of opioids (Ylitalo et al., 2018; Ziadni et al., 2018). Some patients were reluctant to accept a prescription for naloxone since the risk of overdose was viewed as only for those who "abused" opioid medications, had an opioid use disorder, or obtained them illegally (Tiffany et al., 2015). Self-pay or under insured clients had limited access to opioid reversal agents (Devries et al., 2017; Dowell et al., 2016). Identified barriers for providers included time constraints, preconceived ideals surrounding opioid use, and lack of knowledge (Martino et al., 2019; Seal et al., 2019; Wyse et al., 2018).

\section{Recommendation}

All articles emphasized the staggering statistics of accidental overdoses associated with the use of prescription opioids. Death rates are reduced by adopting a combination of assessments, measures, or actions that emphasize changes within healthcare systems. The information provided from the literature review acknowledged common problems with chronic pain patients and offered clinical strategies successful in managing these identified issues. 
Integrating evidenced based changes reduced the risks of death and other harms. In summary, the EBP project change recommendation to develop and implement a safe opioid risk-reduction office policy as a strategy to reduce opioid overdose was fully supported by the evidence.

\section{Setting, Stakeholders, and Systems Change}

The setting for this project was an outpatient interventional pain management clinic specializing in managing patients with chronic pain issues through various evaluations and treatments. This organizational leadership believed in a balanced and multi-disciplinary approach. Medication management was one of the methods used to improve quality of life and activities of daily living for patients suffering from chronic pain. They also promoted injection therapy, chiropractic care, massage, physical therapy, and use of spinal cord stimulators. Depression is a common co-diagnosis for those with long term health problems, and more than half of US adults with mental health diagnoses received a prescribed opioid (Rogers et al., 2020). Recognizing this, the facility evaluated and referred as needed for mood and opioid misuse disorders.

This site facility was one of eight in Pennsylvania. Physicians, physician assistants, or nurse practitioner providers rotated to provide patient care at the different locations. A SWOT analysis was initially created in order to better understand the adjustments needed to successfully implement the EBP project steps. It was important to evaluate the strategic positioning of the organization before developing internal strategies. The individual strength, weaknesses, opportunities, and threats determined are listed in Appendix D.

This micro level practice change project was implemented to directly improve safety through scripted conversation, process measures, and handouts (Nevis et al., 2008). The opportunity to increase the safe use of opioids was first identified through conversation with a 
DNP provider who practiced at the location. There was no formal policy in place with set guidelines or consistency in patient handouts indicating best practice. This project was designed to ensure continuity of care among providers so that all patients received naloxone with instruction, and that understanding of this education was demonstrated. The teach-back method was chosen as an easy method that ensured both parties shared the same information and increased effective communication of health advice or knowledge (Institute for Healthcare Improvement Open School [IHI], 2016).

The stakeholders were internal and external members of the organization. Internal patrons identified were board members, providers, and other employees, such as clerical and clinical support staff. External participants with a vested interest in the clinic were patients and their families, insurance companies, pharmaceutical firms, and government. Organizational support was obtained after meeting with the $\mathrm{CEO}$ and the $\mathrm{CNO}$ to review key elements of the EBP change project.

Further collaboration was necessary from the outside agency Next Harm Reduction, an "online and mail-based harm reduction platform designed to reduce opioid overdose deaths" (Next Harm Reduction, Inc., 2020, para. 1). This non-for-profit organization was the backup source of supply for identified patients who could not obtain naloxone through a local pharmacy. This pilot project was designed to trial at one office with the long-term goal to implement the policy changes at other sites to create sustainable clinical improvements.

\section{Implementation with Timeline and Budget}

The Lewin change theory (1951) guided the development of this project. Driving forces, that facilitate movement to the desired direction, as well as potential inhibiting forces that pushed in the opposite direction, were identified as the pilot project was developed. 
Step one, unfreeze (Lewin, 1951), focused on preparing the patient and provider for changes through staff teaching and online meetings with office staff and providers. The providers were shown the short video from IHI and given the naloxone handout seen in Appendix E to encourage understanding of the teach-back method and adherence. The goals of this stage were to create understanding of why these changes were important and how they would be accomplished. This built motivation and readiness for patient care. Overcoming the identified weakness of the organizational resistance to change relied on the strength of the providers established patient rapport and their willingness to improve the current process. The efforts in Step One were supported by the administration and expert practitioners who recognized the importance of this project, as noted in Appendix D.

Step two, change (Lewin, 1951) involved employee efforts to implement the changes as previously outlined. The project manager (PM) and staff worked together to achieve the desired outcomes of increased naloxone rates and improved patient safety awareness. The front desk staff provided the patient information Naloxone/Narcan Safety and Use and Prescription Opioids: What You Need to Know, listed in Appendix F at the first office visit. The practitioners instructed the patients who verbally indicated needed assistance to obtain naloxone to the Next Distro website. A designated laptop was used to allow them to watch the video and register for home delivery of the reversal agent, as well as an instruction card given so this process could be completed at home. The conversation guide in Appendix G was used to ensure consistency of information and facilitated open communication. The PM was to update in office posters with Narcan or naloxone information as in Appendix $\mathrm{H}$.

Step three, refreezing, accomplished integration of the newly desired behaviors (Lewin, 1951). At the patients four week follow up visit, the provider used the checklist in Appendix I to 
assess understanding of information and confirm naloxone was available to the patient. This information supported the integration of new practices into the organization, as well as identified any needed adjustments to the process. Step three implemented effective behaviors and desired outcomes into the new standard of care and ensured these advances were permanent.

The overall timeframe for the project was eight weeks. The EBP change process and evaluation occurred after obtaining all required course approvals. The USAHS approval process was completed by the Evidence-Based Practice Review Council, and email notification was given prior to implementation. The main project SMART objectives, seen in Appendix J, were as follows:

1. The PM will develop and implement an evidence-based safe opioid risk-reduction office policy for adult patients receiving care in an outpatient chronic pain management clinic by June 1, 2021 (or within 8 weeks of project approval).

2. At the end of the 8-week implementation period, the rate of prescribing provider adherence to concurrent prescription for naloxone therapy with any opioid prescription will increase to a rate of $95 \%$ or greater.

3. At the end of the 8-week implementation period, the rate of initiation to fill naloxone therapy via the patient's pharmacy or Next Distro will increase to a rate of $95 \%$ or greater as determined by provider feedback after they review the PDMP.

4. At the end of the 8-week implementation period, the patient's safe-opioid self-care behaviors knowledge will increase by $50 \%$ or more, post-patient knowledge intervention, as evidenced by the teach back method.

Appendix $\mathrm{J}$ lists team leaders and members involved in the process. A strong understanding of the underlying objectives was critical to convey the purpose behind these changes to the group. 
Open communication between all members included emails to the staff, and board members. The PM direct email and phone number was made available to staff for any questions or concerns. Cost was minimal and met the previously projected amount of less than $\$ 100.00$. The majority was spent on educational handout supplies, the actual cost of printing office posters was higher than anticipated. There were no outside funding sources or additional agency involvement.

\section{Results}

The data was collected at the practice site by one provider due to an unexpected change in staffing. There were no identified HIPAA violations since no records were kept that could identify specific patients. All information was kept confidential and did not recognize patient demographic or include any identifying information. All aggregate data was accessible only to the provider and the PM. The use or disclosure of health information involved no more than a minimal risk to the privacy of individuals. A binder held all the project forms and was locked in the providers office. The analysis was done by the PM with the use of the Intellectus Statistics (2021).

The internally created collection tool in Appendix I was a checklist with face validity and used to accumulate project information. It is a follow up recommendation that this process measure tool be revised to simplify further use as there was some confusion on the pre and post questions. Having the same format for the group one baseline and four-week follow-up group two will strengthen the integrity of the questionnaire and increase the reliability and validity of this assessment for future projects.

All established clinic patients were included in the pilot project. No one declined to participate, all but two were taking opioid prescription medication, and all were English speaking. There were initially 107 participating patients. Two members no longer qualified at the 
four-week follow up and were removed prior to analysis. The project participants self-identified gender and method of payment are listed by percentage in Table 3. Thirty-nine persons identified as male and 68 as female. The most often used payment sources were Medicare and Medicaid.

All categories of measures, benchmarks and statistical tests used to determine the impact of this EBP change project on increased opioid safety are described in Appendix K. Frequencies and percentages were calculated for the 107 patients who received the safety packet, NEXT Distro Narcan information, and were offered a prescription for naloxone at the initial visit at $100 \%$. A majority of the 105 second group participants were able to show knowledge of safeopioid self-care behaviors as assessed by the teach-back method $(\mathrm{n}=102,97 \%)$. The above descriptive data can be seen summarized in Table 4.

A chi-square test of independence was conducted to determine if patients who had unexpired naloxone were independent variables and presented a change between groups 1 and group 2 (IS, 2021). The rate of prescribing provider adherence measured before and after project implementation was determined by the provider checklist. The results of the chi-square test were not significant based on an alpha value of $0.05, \chi 2(1)=2.67, p=.102$ as shown in Table 5. This suggested that the two could be independent of one another and implied that the observed frequencies were not significantly different than the expected frequencies. It is clinically significant to note that 102 patients out of 107 (95\%) already had an unexpired form of naloxone, as verified by the PMP, at the beginning of the project evaluation. This showed the providers were already doing an excellent job of making sure this important reversal agent was available to their patients who were prescribed opioids.

To examine whether a patient was able to verbalize by the teach back method, how and when to correctly use naloxone, a chi-square test of independence was conducted on the group 1 
pre and group 2 post implementation data (IS, 2021). These results of the chi-square test were significant based on an alpha value of $0.05, \chi 2(1)=60.89, p<.001$. This suggested the education provided by the practitioner made an impact on an important component of opioid safety. Table 6 presents the results of the chi-square test.

Also of clinical significance is that 34 Narcan devices were attained via the collaboration between the clinical site and the non-for-profit NEXT Distro organization as shown in Table 4. This provided supplies for patients who financially were not able to obtain this elsewhere through their insurance or local pharmacy. Similar resources for additional clinical sites discovered during this project research were shared with the stakeholders in other states to further support sustainability.

Any improvement in knowledge that increased the safe use of opioid or naloxone availability was determined to be clinically significant. The reduced likelihood of death by overdose was a meaningful clinical change even if not labeled as statistically significant. This EBP project identified need for a consistent source of education, continued provider involvement, and sustained future project implementations at other sites. The interventions effectively impacted the practice concern of opioid safety and risk-reduction that initiated this project.

\section{Impact}

This project was implemented to ensure that a consistent message of safety was presented to the population of patients who required opioids to help manage their chronic pain. Even though opioids have an inherent potential to cause harm, they have been shown to provide effective relief in a certain patient population (Seal et al., 2019; Wyse et al., 2018). Part of the successful use of these medications includes risk mitigation. The providers involved were willing 
to take on the task of delivering the evidenced based steps of the plan designed with the goal of increased safe opioid use behaviors. Based on the data collected during the project, the practitioners were already diligent in ensuring that the reversal agent naloxone was encouraged and prescribed for their patients. This project increased the availably the reversal medication to those patients unable to afford it or were hesitant to recognize the importance of proper opioid storage, disposal, or use. During the previous practice protocol, education was provided, but usually verbally and there were no designated handouts or method to assess comprehension. The EBP changes initiated aligned with the practice guidelines from numerous sources such as the CDC, the U.S. Surgeons General, and the U.S. Department of Health \& Human Service InterAgency Task Force as referenced in Appendix C.

Providing practitioner training, as well as patient education, helped alleviate some of the recognized barriers for naloxone use such as time constraints, preconceived ideals surrounding opioid use, lack of knowledge, and stigma to having or needing a reversal agent (Martino et al., 2019; Seal et al., 2019; Wyse et al., 2018). Providers were introduced to the effectiveness and ease of the teach back method as an educational and evaluation option. This tool can be applied to other aspects of patient care.

Initially, limitations restricted the accessibility of Narcan at no charge to participants who resided in Pennsylvania. During the collaboration with the non-for-profit organizations additional sources were identified that applied to practice sites in other states. This maintains sustainability of the pilot project and supports continuation at additional locations in Virginia, New Jersey, and Maryland. The educational components were well received by both the patients, and stakeholders. They were concluded to be "easy to understand, comprehensive, and welcomed" (G. Hites, personal communication, September 9, 2021). The posters in Appendix H 
were not implemented due to funding issues during this project but will be utilized at subsequent practice sites.

Ongoing evaluation for other office sites will be managed by the provider trainers and individual clinic managers. All resources including patient handouts, provider education, and project data was given to the organization and distributed based on the initial success of this project. Only minimal costs are expected for expansion and are mostly for printing costs. The affordability and simplicity of the project design supports the adaptation of future project changes.

\section{Dissemination}

Within the USAHS facility, a poster board presentation of the EBP change project results was submitted for review on December 12, 2021. The Third-Party Copyright and SOAR@USA Electronic Submission Statements were completed, and the final approved manuscript project was submitted for publishing in the Scholarship and Open Access Repository at USAHS. The authors updated curriculum vitae includes a link to this work.

The conclusion of this EBP change project was presented to the organizational providers and staff after receiving final approval for the project report. This was done via an online Power Point presentation and a copy of the manuscript was emailed to the board members. During the project, the $\mathrm{CEO}$ and $\mathrm{CNO}$, were kept up to date on the progress and findings via email and informal in person conversations.

To allow for a wider dissemination audience, an abstract was submitted to the American Society for Pain Management Nursing for consideration of an evidenced-based practice poster and oral presentation. Journal submissions discussing the practice issue and project findings were 
offered to The Journal of the American Academy of Nurse Practitioners and Pain Management Nursing.

\section{Conclusion}

The EBP change project successfully increased the safe use of prescription opioid medication and in doing so, reduced the risk of overdose or other harms. This was done through implementing an office policy that expanded the availability of naloxone, and improved patient, and provider knowledge. Clinically, this was significant in that the steps taken achieved a reduction of the likelihood of an accidental overdose or death. This project design can easily be applied by healthcare practitioners at other outpatient clinic sites to prevent a significant public health concern. Improvements in health literacy reduce mortality rates as well as the associated costs and effects of an unintended opioid overdose. Enhanced prevention planning and access to reversal treatment options protect patients who use prescriptions opioids. 


\section{References}

Agency for Healthcare Research and Quality. (2019, November). Health Literacy Measurement Tools (Revised). https://www.ahrq.gov/health-literacy/research/tools/index.html American Society of Regional Anesthesia and Pain Medicine. (n.d.). Safe opioid storage, tapering, and disposal. Retrieved January 21, 2021, from https://www.asra.com/patientinformation/opioiduse/safe-opioid-storage-tapering-and-disposal

Centers for Disease Control and Prevention. (2019, August 6). Still not enough naloxone where it's most needed. https://www.cdc.gov/media/releases/2019/p0806-naloxone.html

Centers for Disease Control and Prevention. (2020, December). Multiple cause of death 19992019. CDC WONDER Online Database. https://www.drugabuse.gov/drug-topics/trends$\underline{\text { statistics/overdose-death-rates }}$

City Data. (n.d.). Connellsville, PA. CityData.com. Retrieved January 19, 2021, from https://www.city-data.com/city/Connellsville-Pennsylvania.html

Dang, D., \& Dearholt, S. L. (2017). Johns Hopkins nursing evidence-based practice: Model and guidelines (3rd ed.). Sigma Theta Tau International. https://www.hopkinsmedicine.org/evidence-based-practice/ijhn_2017_ebp.html

Davenport, S., Weaver, A., \& Caverly, M. (2019). Economic impact of non-medical opioid use in the United States (Annual estimates and projections for 2015 through 2019). Society of Actuaries. https://www.soa.org/globalassets/assets/files/resources/researchreport/2019/econ-impact-non-medical-opioid-use.pdf

Denault, D., Wilcox, M., Breda, K., Duhamel, K., \& Eichar, S. (2019, June 11). Teach-back: An underutilized tool. American Nurse. https://www.myamericannurse.com/teach-back-an$\underline{\text { underutilized-tool/ }}$ 
Devries, J., Rafie, S., \& Polston, G. (2017). Implementing an overdose education and naloxone distribution program in a health system. Journal of the American Pharmacists Association, 57(2), S154-S160. https://doi.org/10.1016/j.japh.2017.01.002

Dowell, D., Haegerich, T. M., \& Chou, R. (2016). CDC guideline for prescribing opioids for chronic pain: United States. MMWR Recommendations and Reports, 65(1), 1-49. https://doi.org/10.15585/mmwr.rr6501e1

Ducoffe, A. R., York, A., Hu, D. J., Perfetto, D., \& Kerns, R. D. (2016). National action plan for adverse drug event prevention: Recommendations for safer outpatient opioid use. Pain Medicine, 17(12), 2291-2304. https://doi.org/10.1093/pm/pnw106

Echevarria, I. M., \& Walker, S. (2014). To make your case, start with a PICOT question. Nursing, 44(2), 18-19. https://doi.org/10.1097/01.nurse.0000442594.00242.f9

Florence, C., Luo, F., \& Rice, K. (2021). The economic burden of opioid use disorder and fatal opioid overdose in the United States, 2017. Drug and Alcohol Dependence, 218, 108350. https://doi.org/10.1016/j.drugalcdep.2020.108350

Frieden, T., \& Houry, D. (2016). Reducing the risks of relief: The CDC opioid-prescribing guideline. New England Journal of Medicine, 374(1), 1501-1504. https://doi.org/10.1056/NEJMp1515917

Highland, K., Giordano, N. A., Kirk, K., Rojas, W., Robinson-Morris, L., \& Krzyzek, M. (2020). App-based pain management and opioid education program for patients in clinic waiting rooms. Pain Management Nursing. https://doi.org/10.1016/j.pmn.2020.10.007

Intellectus Statistics. [Online computer software]. (2021).https://analyze.intellectusstatistics.com/ Institute for Healthcare Improvement Open School. (2016, February 4). What Is Teach-Back? [Video]. YouTube. https://www.youtube.com/watch?v=bzpJJYF_tKY 
Highland, K., Giordano, N. A., Kirk, K., Rojas, W., Robinson-Morris, L., \& Krzyzek, M. (2020). App-based pain management and opioid education program for patients in clinic waiting rooms. Pain Management Nursing. https://doi.org/10.1016/j.pmn.2020.10.007

Jones, L. K., Lussier, M. E., Brar, J., Byrne, M. C., Durham, M., Kiokemeister, F., Kjaer, K., Le, H., Magee, C., McKnight, E., Mehta, N., Papp, J., Pastwa, E., Radovich, P., Ravin, K., Ruther, M., Woodie, G., Wrona, S., Yousefvand, G., \& Greskovic, G. (2019). Current interventions to promote safe and appropriate pain management. American Journal of Health-System Pharmacy, 76(11), 829-834. https://doi.org/10.1093/ajhp/zxz063

Kadakia, N. N., Rogers, R. L., Reed, J. B., Dark, E. R., \& Plake, K. (2020). Patient education interventions for prescription opioids: A systematic review. Journal of the American Pharmacists Association, 60(4), e31-e42. https://doi.org/10.1016/j.japh.2020.02.013

Lewin, K. (1951). Field theory in social science: Selected theoretical papers (D. Cartwright, Ed.). Harpers.

Marszalek, D., Martinson, A., Smith, A., Marchand, W., Sweeney, C., Carney, J., Lowery, T., \& Clinton-Lont, J. (2020). Examining the effect of a whole health primary care pain education and opioid monitoring program on implementation of VA/DoD-recommended guidelines for long-term opioid therapy in a primary care chronic pain population. Pain Medicine, 21(10), 2146-2153. https://doi.org/10.1093/pm/pnaa155

Martino, J. G., Smith, S. R., Rafie, S., Rafie, S., \& Marienfeld, C. (2019). Physician and pharmacist: Attitudes, facilitators, and barriers to prescribing naloxone for home rescue. The American Journal on Addictions, 29(1), 65-72. https://doi.org/10.1111/ajad.12982 
National Institutes of Health. (2017, March 30). Naloxone for opioid overdose: Life-saving science. National Institute on Drug Abuse. https://www.drugabuse.gov/publications/naloxone-opioid-overdose-life-saving-science

Neville, K., \& Foley, M. (2020). The economic impact of the opioid use disorder epidemic in America: Nurses' call to action. Nursing Economic\$, 38(1), 7-51. http://www.nursingeconomics.net/necfiles/2020/JF20/7.pdf

Nevis, E., Melnick, J., \& Nevis, S. (2008). Organizational Change through Powerful MicroLevel Interventions. OD Practitioner, 40(3), 4-8. http://www.josephmelnickphd.com/wpcontent/uploads/2016/Articles/ODP.pdf

Next Harm Reduction, Inc. (2020). NEXT distro. https://nextdistro.org/

Rogers, A. H., Orr, M. F., Shepherd, J. M., Bakhshaie, J., Ditre, J. W., Buckner, J. D., \& Zvolensky, M. J. (2020). Anxiety, depression, and opioid misuse among adults with chronic pain: The role of emotion dysregulation. Journal of Behavioral Medicine, 44(1), 66-73. https://doi.org/10.1007/s10865-020-00169-8

Seal, K. H., Borsari, B., Tighe, J., Cohen, B. E., Delucchi, K., Morasco, B. J., Li, Y., Sachs, E., Abadjian, L., Watson, E. C., Manuel, J. K., Vella, L., Trafton, J., \& Midboe, A. (2019). Optimizing pain treatment interventions (OPTI): A pilot randomized controlled trial of collaborative care to improve chronic pain management and opioid safety-rationale, methods, and lessons learned. Contemporary Clinical Trials, 77, 76-85. https://doi.org/10.1016/j.cct.2018.12.006

Tiffany, E., Wilder, C. M., Miller, S. C., \& Winhusen, T. (2015). Knowledge of and interest in opioid overdose education and naloxone distribution among us veterans on chronic 
opioids for addiction or pain. Drugs: Education, Prevention and Policy, 23(4), 322-327. https://doi.org/10.3109/09687637.2015.1106442

U.S. Department of Health \& Human Services. (2017, December 15). Attachment B:

Recommendations on the interpretation and application of $\S_{-} .104(d)(4)$. HHS.gov. https://www.hhs.gov/ohrp/sachrp-committee/recommendations/attachment-b-december12-2017/index.html

U.S Department of Health and Human Services. (2018a). Naloxone: The opioid reversal drug that saves lives. Office of the Surgeon General.

https://www.hhs.gov/opioids/sites/default/files/2018-12/naloxone-coprescribingguidance.pdf

U.S. Department of Health and Human Services. (2018b). US Surgeon General's advisory of naloxone and opioid overdose. Office of the Surgeon General. https://www.hhs.gov/surgeongeneral/priorities/opioids-and-addiction/naloxoneadvisory/index.html

Wang, C., Bakhet, M., Roberts, D., Gnani, S., \& El-Osta, A. (2020). The efficacy of microlearning in improving self-care capability: A systematic review of the literature. Public Health, 186, 286-296. https://doi.org/10.1016/j.puhe.2020.07.007

Wyse, J. J., Ganzini, L., Dobscha, S. K., Krebs, E. E., Zamudio, J., \& Morasco, B. J. (2018). Clinical strategies for the treatment and management of patients prescribed long-term opioid therapy. Pain Medicine, 20(9), 1737-1744. https://doi.org/10.1093/pm/pny211

Ylitalo, K. R., Meyer, M., Lanning, B. A., During, C., Laschober, R., \& Griggs, J. O. (2018). Simple screening tools to identify limited health literacy in a low-income patient population. Medicine, 97(10), e0110. https://doi.org/10.1097/md.0000000000010110 
Ziadni, M., You, D. S., Wilson, A. C., \& Darnall, B. D. (2018). Care scale 7. The Clinical Journal of Pain, 34(9), 818-824. https://doi.org/10.1097/ajp.0000000000000606 


\section{Table 1}

Quality Guide Summary

\begin{tabular}{lllll}
\hline $\begin{array}{l}\text { evidence } \\
\text { level }\end{array}$ & $\begin{array}{l}\text { a: } \\
\text { high } \\
\text { quality }\end{array}$ & $\begin{array}{l}\text { a/b: } \\
\text { high/good } \\
\text { quality }\end{array}$ & $\begin{array}{l}\text { b: } \\
\text { good } \\
\text { quality }\end{array}$ & $\begin{array}{l}\text { low } \\
\text { quality }\end{array}$ \\
\hline I & 3 & & 1 & \\
$(4 / 14)$ & & & \\
II & 2 & 1 & \\
$(3 / 14)$ & & & \\
III & 1 & 2 & & \\
$(3 / 14)$ & & & \\
IV & 3 & & \\
$(3 / 14)$ & & & \\
V & & & \\
$(1 / 14)$ & 1 & & \\
\hline
\end{tabular}


Table 2

Drug Overdose Deaths Involving Natural and Semisynthetic Opioids Male/Female Combined

\begin{tabular}{|c|c|c|c|c|c|c|c|c|c|}
\hline Year & 1999 & 2000 & 2005 & 2010 & 2012 & 2013 & 2014 & 2015 & 2016 \\
\hline White & 2.2 & 2.3 & 4.4 & 8.3 & 8.2 & 8.2 & 8.7 & 9.0 & 10.2 \\
\hline $\begin{array}{l}\text { Black or } \\
\text { African } \\
\text { American }\end{array}$ & 1.3 & 1.2 & 1.9 & 3.0 & 3.0 & 3.5 & 3.9 & 4.1 & 5.3 \\
\hline $\begin{array}{l}\text { American } \\
\text { Indian or } \\
\text { Alaska } \\
\text { Native }\end{array}$ & $*$ & $*$ & 4.1 & 6.4 & 10.5 & 7.3 & 8.2 & 7.6 & 7.1 \\
\hline $\begin{array}{l}\text { Asian or } \\
\text { Pacific } \\
\text { Islander }\end{array}$ & $*$ & $*$ & 0.3 & 0.9 & 0.9 & 0.8 & 0.9 & 0.8 & 1.1 \\
\hline $\begin{array}{l}\text { Hispanic } \\
\text { or Latino }\end{array}$ & 2.6 & 1.8 & 2.1 & 2.4 & 2.8 & 3.0 & 2.8 & 2.9 & 3.2 \\
\hline $\begin{array}{l}\text { White, } \\
\text { not } \\
\text { Hispanic } \\
\text { or Latino }\end{array}$ & 2.0 & 2.4 & 4.9 & 9.5 & 9.3 & 9.4 & 10 & 10.6 & 11.9 \\
\hline $\begin{array}{l}\text { Black, } \\
\text { not } \\
\text { Hispanic } \\
\text { or Latino }\end{array}$ & 1.3 & 1.2 & 2.0 & 2.8 & 3.1 & 3.3 & 4 & 4.3 & 5.6 \\
\hline
\end{tabular}

Note. * Missing data; Numbers are per 100,000 resident population. Race, gender, year groups and cause of death involving natural and semisynthetic opioids were used to compile data from the 1999-2019 CDC Wonder Online Database retrieved January 23, 2021 https://wonder.cdc.gov/controller/datarequest/D76;jsessionid=3222538284C09A233E33AB342F B4. In the public domain. 


\section{Table 3}

Frequency Table for Nominal Variables

\begin{tabular}{lccc}
\hline & \multicolumn{3}{c}{ Group } \\
\cline { 2 - 4 } Variable & 1 & 2 & Missing \\
\hline Sex & & & \\
F & $68(64 \%)$ & $65(62 \%)$ & $0(0 \%)$ \\
M & $39(36 \%)$ & $40(38 \%)$ & $0(0 \%)$ \\
Missing & $0(0 \%)$ & $0(0 \%)$ & $0(0 \%)$ \\
Total & $107(100 \%)$ & $105^{*}(100 \%)$ & $0(100 \%)$ \\
MOP & & & \\
MD & $45(42 \%)$ & $40(38 \%)$ & $0(0 \%)$ \\
C & $29(27 \%)$ & $22(21 \%)$ & $0(0 \%)$ \\
MC & $32(30 \%)$ & $43(41 \%)$ & $0(0 \%)$ \\
SP & $1(1 \%)$ & $0(0 \%)$ & $0(0 \%)$ \\
Missing & $0(0 \%)$ & $0(0 \%)$ & $0(0 \%)$ \\
Total & $107(100 \%)$ & $105^{*}(100 \%)$ & $0(100 \%)$ \\
\hline
\end{tabular}

Note $. \mathrm{MOP}=$ method of payment; $\mathrm{MD}=$ Medicaid, $\mathrm{C}=$ Commercial insurance, $\mathrm{MC}=$ Medicare, $\mathrm{SP}=$ Self-pay $*$ Two participants no longer qualified at the four-week follow up. 


\section{Table 4}

Frequency Table for Nominal Variables

\begin{tabular}{|c|c|c|c|}
\hline \multirow[b]{2}{*}{ Variable } & \multicolumn{3}{|c|}{ Group } \\
\hline & 1 & 2 & Missing \\
\hline \multicolumn{4}{|c|}{ Pt received safety pkt. } \\
\hline $\mathrm{Y}$ & $107(100 \%)$ & $0(0 \%)$ & $0(0 \%)$ \\
\hline Missing & $0(0 \%)$ & & $0(0 \%)$ \\
\hline Total & $107(100 \%)$ & & $0(100 \%)$ \\
\hline \multicolumn{4}{|c|}{ Pt. Received NEXT Narcan Info } \\
\hline Y & $107(100 \%)$ & & $0(0 \%)$ \\
\hline Missing & $0(0 \%)$ & & $0(0 \%)$ \\
\hline Total & $107(100 \%)$ & & $0(100 \%)$ \\
\hline \multicolumn{4}{|c|}{ Pt offered RX } \\
\hline $\mathrm{Y}$ & $107(100 \%)$ & & $0(0 \%)$ \\
\hline Missing & $0(0 \%)$ & & $0(0 \%)$ \\
\hline Total & $107(100 \%)$ & & $0(100 \%)$ \\
\hline \multicolumn{4}{|c|}{ NARCAN received from NEXT Distro } \\
\hline $\mathrm{N}$ & & $71(68 \%)$ & $0(0 \%)$ \\
\hline $\mathrm{Y}$ & & $34(32 \%)$ & $0(0 \%)$ \\
\hline Missing & & $0(0 \%)$ & $0(0 \%)$ \\
\hline Total & & $105(100 \%)$ & $0(100 \%)$ \\
\hline \multicolumn{4}{|c|}{ Able to TB safe opioid use } \\
\hline Y & & $102(97 \%)$ & $0(0 \%)$ \\
\hline $\mathrm{N}$ & & $3(3 \%)$ & $0(0 \%)$ \\
\hline Missing & & $0(0 \%)$ & $0(0 \%)$ \\
\hline Total & & $105(100 \%)$ & $0(100 \%)$ \\
\hline
\end{tabular}

Note. Due to rounding error, percentages may not sum to $100 \%$. 


\section{Table 5}

\section{Observed and Expected Frequencies}

\begin{tabular}{lccccc}
\hline & \multicolumn{5}{c}{ Group } \\
Pt. has unexpired naloxone & 1 & 2 & $\chi^{2}$ & $d f$ & $p$ \\
\cline { 2 - 6 } & $102[103.97]$ & $104[102.03]$ & 2.67 & 1 & .102 \\
$\mathrm{Y}$ & $5[3.03]$ & $1[2.97]$ & & & \\
$\mathrm{N}$ & & & & & \\
\hline
\end{tabular}

Note. Pt., patient; Values formatted as Observed [Expected]. 


\section{Table 6}

Observed and Expected Frequencies

\begin{tabular}{lrrrrrr}
\hline & \multicolumn{5}{c}{ Group } & \\
\cline { 2 - 6 } & & 1 & 2 & $\chi^{2}$ & $d f$ & $p$ \\
\hline $\mathrm{Y}$ & & & & & & \\
\hline $\mathrm{N}$ & $59[82.77]$ & $105[81.23]$ & 60.89 & 1 & $<.001$ \\
& & & & & \\
& $48[24.23]$ & $0[23.77]$ & & & \\
\hline
\end{tabular}

Note. Pt., patient; Values formatted as Observed [Expected]. 


\section{Figure 1}

\section{Lewin Change Theory}

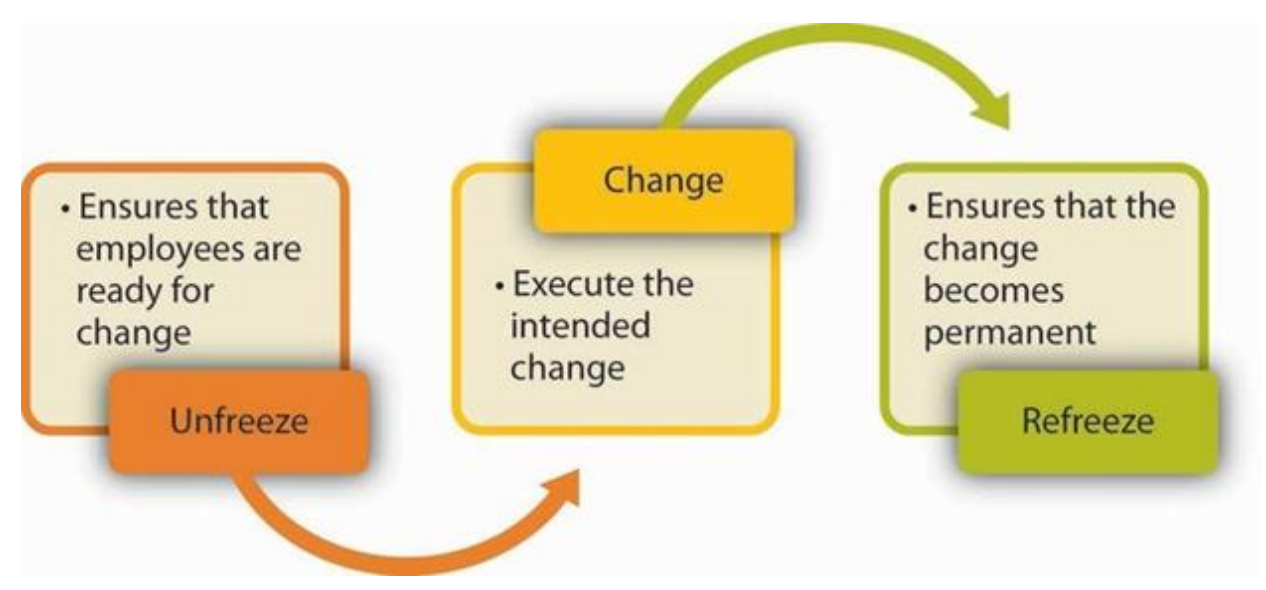

Note. Figure depicting the stages of Lewin change theory "unfreeze" "change" and "refreeze".

From Principles of Management, (p. 304), 2012, Saylor Academy.

(https://resources.saylor.org/wwwresources/archived/site/textbooks/Principles\%20of\%20Manage

ment.pdf). CC BY NC-SA 3.0. 


\section{Figure 2}

\section{PRISMA Diagram}
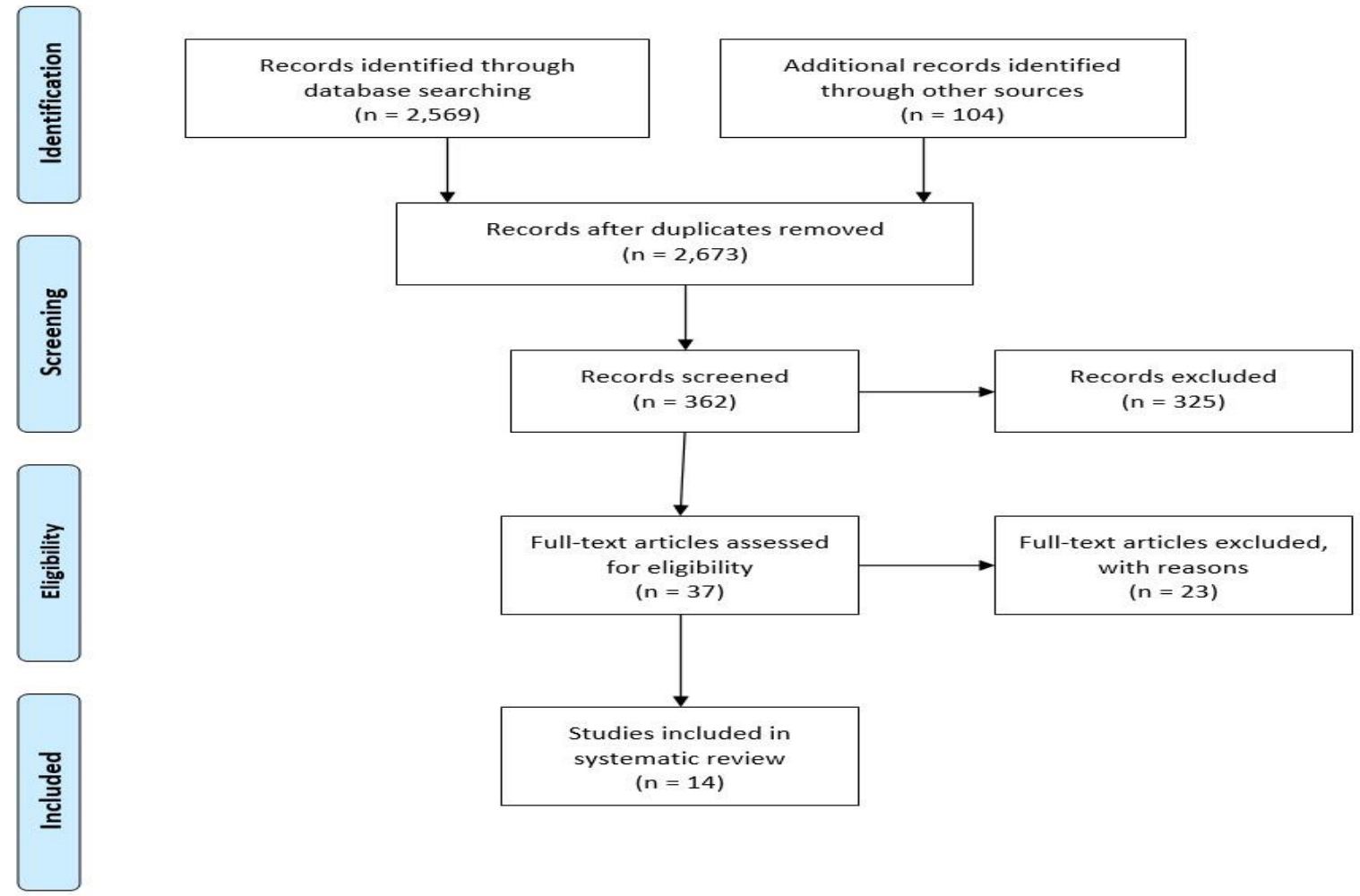

Note. Flow of information through the different phases of the EBP Change project literature search strategy. Adapted from: "Preferred Reporting Items for Systematic Reviews and MetaAnalyses: The PRISMA Statement," by D. Moher, A. Liberati, J.Tetzlaff, and D. G. Altman, PLoS Med 6(7): e1000097 (doi:10.1371/journal.pmed1000097). Copyright 2009 by The PRISMA Group. 


\section{Figure 3}

National Overdose Deaths Involving Prescription Opioids

Figure 4. National Drug Overdose Deaths Involving Prescription Opioids*, Number Among All Ages, 1999-2019

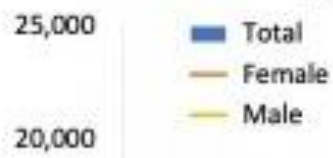

Note. Statistics taken from deaths involving many of the more commonly used drugs available through 2019. From the 1999-2009 CDC Wonder Online Database, released 12/2020. (https://www.drugabuse.gov/drug-topics/trends-statistics/overdose-death-rates). In the public domain. 


\section{Appendix A}

\section{Primary Research Review}

\begin{tabular}{|c|c|c|c|c|c|c|c|}
\hline & & & $\begin{array}{l}\text { PICOT EBP } \\
\text { In adult patier } \\
\text { implementatic } \\
\text { improve patie }\end{array}$ & $\begin{array}{l}\text { JESTION: } \\
\text { s at an outpatient chronic pa } \\
\text { of a safe opioid risk-reduct } \\
\text { rates of naloxone availabil }\end{array}$ & $\begin{array}{l}\text { n management clin } \\
\text { on office policy (I) } \\
\text { ty and health literac }\end{array}$ & $\begin{array}{l}\text { (P), how does developme } \\
\text { ompared to usual practice } \\
\text { O) over four weeks (T) }\end{array}$ & $\begin{array}{l}\text { and } \\
\text { C), }\end{array}$ \\
\hline \multirow{2}{*}{$\begin{array}{l}\text { Articl } \\
\text { e } \\
\text { Numb } \\
\text { er }\end{array}$} & \multirow[t]{2}{*}{$\begin{array}{l}\text { Author } \\
\text { and Date } \\
\text { Published }\end{array}$} & \multirow[t]{2}{*}{\begin{tabular}{|l} 
Evidence \\
Type
\end{tabular}} & $\begin{array}{l}\text { Sample } \\
\text { Size }\end{array}$ & \multirow[t]{2}{*}{$\begin{array}{l}\text { Findings Related to } \\
\text { PICOT Question }\end{array}$} & \multirow[t]{2}{*}{ Measures } & \multirow[t]{2}{*}{ Limitations } & \multirow[t]{2}{*}{$\begin{array}{l}\text { Evidence } \\
\text { Level } \\
\text { Quality }\end{array}$} \\
\hline & & & Setting & & & & \\
\hline \multirow[b]{2}{*}{1.} & \multirow[t]{2}{*}{$\begin{array}{l}\text { Devries, J., } \\
\text { et al. } \\
(2017) \text {. }\end{array}$} & \multirow{2}{*}{$\begin{array}{l}\text { Quantitative } \\
\text { Quasi- } \\
\text { experimental } \\
\text { Study }\end{array}$} & $\begin{array}{l}\mathrm{N}=252 \\
\text { Naloxone } \\
\text { prescriptions }\end{array}$ & \multirow{2}{*}{$\begin{array}{l}\text { 1. The steady increase in } \\
\text { nalox per month } \\
\text { correlates with increased } \\
\text { provider trainings and } \\
\text { EHR alerts. } \\
\text { 2. Source of EHR alerts } \\
\text { and changes } \\
\text { 3. Naloxone Prescribing } \\
\text { Guidelines } \\
\text { 4. Overdose education } \\
\text { and naloxone distribution } \\
\text { program } \\
\text { checklist } \\
5 . \text { Naloxone was } \\
\text { prescribed in response to } \\
13.8 \%(41 / 252) \text { of the } \\
\text { EHR alerts }\end{array}$} & \multirow{2}{*}{$\begin{array}{l}\text { Nalox by month } \\
\text { compared over } 9 \\
\text { months pre- and } \\
\text { post-policy } \\
\text { change. } \\
\text { Demographics of } \\
\text { provider, } \\
\text { department, and } \\
\text { patient } \\
\text { EHR summary } \\
\text { report records }\end{array}$} & \multirow{2}{*}{$\begin{array}{l}\text {-large, multi-site health } \\
\text { system } \\
\text { - hospital based study } \\
\text { - pharmacist, techs, ER } \\
\text { department and large } \\
\text { education department } \\
\text { staffing }\end{array}$} & \multirow[t]{2}{*}{$\begin{array}{l}\text { Level II } \\
\text { A }\end{array}$} \\
\hline & & & $\begin{array}{l}\text { Large } \\
\text { academic } \\
\text { hospital } \\
\text { healthcare } \\
\text { system }\end{array}$ & & & & \\
\hline 2. & $\begin{array}{l}\text { Highland, } \\
\text { K. B., et al. } \\
(2020) \text {. }\end{array}$ & $\begin{array}{l}\text { Quantitative } \\
\text { Quasi- } \\
\text { experimental } \\
\text { Study }\end{array}$ & $\begin{array}{l}\mathrm{N}=152 \\
\text { Patients }\end{array}$ & $\begin{array}{l}\text { 1. Support for and source } \\
\text { of patient, family } \\
\text { member, clinician } \\
\text { educational videos }\end{array}$ & $\begin{array}{l}\text { Anonymous } \\
\text { feedback survey } \\
\text { (demographics, } \\
\text { video rating, } \\
\text { educational } \\
\text { approach) }\end{array}$ & $\begin{array}{l}\text {-both pain management } \\
\text { and primary care } \\
\text { settings in military- } \\
\text { based clinics } \\
\text {-pilot study }\end{array}$ & $\begin{array}{l}\text { Level II } \\
\text { A }\end{array}$ \\
\hline
\end{tabular}




\begin{tabular}{|c|c|c|c|c|c|c|c|}
\hline & & & & $\begin{array}{l}\text { 2. Support for and tool } \\
\text { for improved clinical pain } \\
\text { assessment/DVPRS } \\
\text { 3. New pain paradigm- } \\
\text { self-management, opioid } \\
\text { risk mitigation practices } \\
\text { and informed consent }\end{array}$ & $\begin{array}{l}\text { 5-point Likert } \\
\text { scale } \\
\text { Three yes/no } \\
\text { assessment } \\
\text { questions }\end{array}$ & $\begin{array}{l}\text {-patient anonymity } \\
\text { prevents follow up }\end{array}$ & \\
\hline & $\begin{array}{l}\text { Marszalek, } \\
\text { D., et al. } \\
(2020) .\end{array}$ & $\begin{array}{l}\text { Quantitative } \\
\text { experimental } \\
\text { Study }\end{array}$ & $\begin{array}{l}\mathrm{N}=50 \\
\text { subjects } \\
\text { predominatel } \\
\text { y male and } \\
\text { white/non- } \\
\text { Hispanic, } \\
\text { with an } \\
\text { average age } \\
\text { (range) of } 62 \\
\text { years. }\end{array}$ & \multirow{2}{*}{$\begin{array}{l}\text { 1.Education (via } \\
\text { PowerPoint) that describe } \\
\text { what opioids are and how } \\
\text { to recognize and respond } \\
\text { to an overdose (e.g., } \\
\text { naloxone education) } \\
\text { 2. Statistics re: } \\
\text { unintentional opioid } \\
\text { overdose and how } \\
\text { veterans are particularly } \\
\text { at risk. } \\
\text { 3. Medication storage } \\
\text { safety } \\
\text { 4. Risks associated with } \\
\text { co-ingesting opioids with } \\
\text { alcohol, other drugs, and } \\
\text { sedating medications (i.e., } \\
\text { benzodiazepines) }\end{array}$} & \multirow{2}{*}{$\begin{array}{l}\text { means between } \\
\text { groups (PC-POP } \\
\text { enrollees vs the } \\
\text { comparison group) } \\
\text { and within groups } \\
\text { (PC-POP enrollees } \\
\text { only, } \\
\text { before and after } \\
\text { six months of PC- } \\
\text { POP enrollment) } \\
\text { preliminary } \\
\text { independent- } \\
\text { samples t tests } \\
\text { utilizing the two- } \\
\text { tailed significance } \\
\text { test and 95\% } \\
\text { confidence } \\
\text { intervals. } \\
\text { generalized linear } \\
\text { modeling (GLM) } \\
\text { and a single } \\
\text { paired-sample t } \\
\text { test (for the } \\
\text { individual } \\
\text { continuous } \\
\text { variable, MEDD) } \\
\text { to examine } \\
\text { whether } \\
\text { differences were }\end{array}$} & \multirow[t]{2}{*}{$\begin{array}{l}\text {-small sample size } \\
\text {-veterans in } \\
\text { primary care at one } \\
\text { geographical site- lack } \\
\text { of generalizability } \\
\text {-sample of convenience } \\
\text {-mostly male white } \\
\text { patients }\end{array}$} & \multirow[t]{2}{*}{$\begin{array}{l}\text { Level I } \\
\mathrm{B}\end{array}$} \\
\hline 3. & & & $\begin{array}{l}\text { Veterans in } \\
\text { primary care } \\
\text { setting }\end{array}$ & & & & \\
\hline
\end{tabular}




\begin{tabular}{|c|c|c|c|c|c|c|c|}
\hline & & & & & $\begin{array}{l}\text { statistically } \\
\text { significant before } \\
\text { engagement in the } \\
\text { PC-POP vs post- } \\
\text { PC-POP } \\
\text { engagement } \\
\text { UDS }\end{array}$ & & \\
\hline \multirow[b]{2}{*}{4.} & \multirow[t]{2}{*}{$\begin{array}{l}\text { Martino, } \\
\text { J.G., et al. } \\
(2019) \text {. }\end{array}$} & \multirow{2}{*}{$\begin{array}{l}\text { Mixed } \\
\text { methods } \\
\text { Cross- } \\
\text { sectional } \\
\text { Study }\end{array}$} & $\begin{array}{l}\mathrm{N}=72 \\
\text { Physicians } \\
\text { and } \\
\text { pharmacists }\end{array}$ & \multirow{2}{*}{$\begin{array}{l}\text { 1. Identification of } \\
\text { barriers to Nalox } \\
\text { 2. Support of provider } \\
\text { education and training } \\
\text { specifically regarding } \\
\text { Nalox }\end{array}$} & \multirow[t]{2}{*}{$\begin{array}{l}\text { Questionnaire } \\
\text { Interviews }\end{array}$} & \multirow[t]{2}{*}{$\begin{array}{l}\text { - small study sample } \\
\text { size } \\
\text {-limited to physicians } \\
\text { and pharmacists }\end{array}$} & \multirow[t]{2}{*}{$\begin{array}{l}\text { Level I } \\
\text { A }\end{array}$} \\
\hline & & & $\begin{array}{l}\text { Large } \\
\text { academic } \\
\text { hospital } \\
\text { healthcare } \\
\text { system } \\
\end{array}$ & & & & \\
\hline \multirow[b]{2}{*}{5.} & \multirow[t]{2}{*}{$\begin{array}{l}\text { Seal, K. H., } \\
\text { et al. } \\
(2019)\end{array}$} & \multirow[t]{2}{*}{$\begin{array}{l}\text { Mixed } \\
\text { Method; } \\
\text { Explanatory } \\
\text { Randomized } \\
\text { Controlled } \\
\text { Trial (RTC) }\end{array}$} & $\begin{array}{l}\mathrm{N}=100 \\
\text { Patients }\end{array}$ & \multirow{2}{*}{$\begin{array}{l}\text { 1. Support use of } \\
\text { SMART patient goals } \\
\text { 2. Internal validity } \\
\text { increased when objective } \\
\text { measures are combined } \\
\text { with clinical measures. } \\
\text { 3. Collaborative Care } \\
\text { Model with motivational } \\
\text { interviewing effective } \\
\text { measurement of patient } \\
\text { education } \\
\text { 4. Support for and source } \\
\text { of patient-centered } \\
\text { educational materials }\end{array}$} & \multirow{2}{*}{$\begin{array}{l}\text { Current Opioid } \\
\text { Misuse Measure } \\
\text { The Brief Pain } \\
\text { Inventory } \\
\text { The World Health } \\
\text { Organization } \\
\text { Alcohol, Smoking, } \\
\text { and Substance } \\
\text { Involvement } \\
\text { Screening Test } \\
\text { The Pain } \\
\text { Treatment } \\
\text { Satisfaction Scale } \\
\text { The Patient Health } \\
\text { Questionnaire } \\
\text { The Addictions } \\
\text { Behavior } \\
\text { Checklist } \\
\text { Urine Drug Screen }\end{array}$} & \multirow[t]{2}{*}{$\begin{array}{l}\text {-primary care setting } \\
\text {-pilot study } \\
\text {-mostly descriptive } \\
\text { analyses results }\end{array}$} & \multirow[t]{2}{*}{$\begin{array}{l}\text { Level I } \\
\text { A }\end{array}$} \\
\hline & & & $\begin{array}{l}\text { VA primary } \\
\text { care office }\end{array}$ & & & & \\
\hline
\end{tabular}




\begin{tabular}{|c|c|c|c|c|c|c|c|}
\hline & & & & & $\begin{array}{l}\text { Alcohol } \\
\text { Breathalyzer }\end{array}$ & & \\
\hline & $\begin{array}{l}\text { Tiffany, E., } \\
\text { et al. } \\
(2015) \text {. }\end{array}$ & $\begin{array}{l}\text { Qualitative } \\
\text { Descriptive }\end{array}$ & $\mathrm{N}=90 \mathrm{pts}$ & $\begin{array}{l}\text { 1. overdose education } \\
\text { and naloxone distribution } \\
\text { OEND programs in the }\end{array}$ & $\begin{array}{l}\text { Structured } 30 \mathrm{~min} \\
\text { interview. } \\
\text { DAST-10 }\end{array}$ & $\begin{array}{l}\text { - sampling } \\
\text { was not randomized. } \\
\text {-pts limited to the VA }\end{array}$ & $\begin{array}{l}\text { Level III } \\
\mathrm{A} / \mathrm{B}\end{array}$ \\
\hline 6. & & Study & $\begin{array}{l}\text { Veterans } \\
\text { receiving } \\
\text { opioids for } \\
>3 \text { months }\end{array}$ & $\begin{array}{l}\text { US helped to rescue more } \\
\text { than } \\
10,000 \text { individuals from } \\
\text { opioid overdoses from } \\
1996 \text { to } 2010 \\
2 . \text { Veterans surveyed } \\
\text { appeared comfortable } \\
\text { with the idea of } \\
\text { using naloxone kits to } \\
\text { prevent OOD and many } \\
\text { were interested in } \\
\text { receiving a kit. } \\
\text { 3. intranasal spray kit } \\
\text { preferred over injection } \\
\text { kit }\end{array}$ & AUDIT-C & $\begin{array}{l}\text {-some prior pts in one } \\
\text { group had had previous } \\
\text { opioid education } \\
-93 \% \text { male pts }\end{array}$ & \\
\hline \multirow[b]{2}{*}{7.} & \multirow[t]{2}{*}{$\begin{array}{l}\text { Wyse, J. J., } \\
\text { et al. } \\
\text { (2019). }\end{array}$} & \multirow{2}{*}{$\begin{array}{l}\text { Qualitative } \\
\text { Descriptive } \\
\text { Study }\end{array}$} & $\begin{array}{l}\mathrm{N}=24 \\
\text { clinicians }\end{array}$ & \multirow{2}{*}{$\begin{array}{l}\text { 1. changes to policy and } \\
\text { practice designed to } \\
\text { promote safer prescribing } \\
\text { and patient care } \\
\text { 2. recognition of the } \\
\text { harms associated with } \\
\text { long-term opioid therapy } \\
\text { (LTOT) } \\
\text { 3. initiatives providers } \\
\text { utilized to meet opioid }\end{array}$} & \multirow{2}{*}{$\begin{array}{l}\text { qualitative content } \\
\text { analysis } \\
\text { AtlasTI, version } 7 \\
\text { was used to } \\
\text { organize and code } \\
\text { the data group } \\
\text { coding process, } \\
\text { interviews were } \\
\text { divided and first } \\
\text { coded }\end{array}$} & \multirow{2}{*}{$\begin{array}{l}\text {-small qualitative } \\
\text { sample } \\
\text { obtained through } \\
\text { convenience sampling } \\
\text { methods } \\
\text {-all providers who } \\
\text { participated in the study } \\
\text { were currently } \\
\text { employed within VA } \\
\text { hospitals }\end{array}$} & \multirow[t]{2}{*}{$\begin{array}{l}\text { Level III } \\
\text { A/B }\end{array}$} \\
\hline & & & $\begin{array}{l}\text { Department } \\
\text { of Veterans } \\
\text { Affairs }\end{array}$ & & & & \\
\hline
\end{tabular}




\begin{tabular}{|c|c|c|c|c|c|c|c|}
\hline & & & & $\begin{array}{l}\text { safety requirements and } \\
\text { address common } \\
\text { challenges in caring for } \\
\text { patients. } \\
\text { 4. information to } \\
\text { implement new } \\
\text { guidelines. } \\
\text { around opioid } \\
\text { management and } \\
\text { minimize the potential for } \\
\text { patients to experience } \\
\text { opioid-related harms }\end{array}$ & $\begin{array}{l}\text { independently and } \\
\text { then exchanged } \\
\text { for secondary } \\
\text { coding }\end{array}$ & $\begin{array}{l}\text {-may be different } \\
\text { regulations based on } \\
\text { State of practice }\end{array}$ & \\
\hline \multirow[b]{2}{*}{8.} & \multirow[t]{2}{*}{$\begin{array}{l}\text { Ziadni, M., } \\
\text { et al. } \\
(2018)\end{array}$} & \multirow[t]{2}{*}{$\begin{array}{l}\text { Multiphasic } \\
\text { RTC Study }\end{array}$} & $\begin{array}{l}\text { Phase I } \\
\mathrm{N}=729 \text { clinic } \\
\text { pts } \\
\text { Phase II } \\
\mathrm{N}=578 \text { online } \\
\text { pts } \\
\mathrm{N}=145 \text { in } \\
\text { clinic pts }\end{array}$ & \multirow[t]{2}{*}{$\begin{array}{l}\text { 1. The CARE scale is a } \\
\text { brief, integrated measure } \\
\text { that may be used to reveal } \\
\text { specific interpersonal and } \\
\text { personal impediments to } \\
\text { self-care, and identify } \\
\text { important therapeutic } \\
\text { targets to optimize self- } \\
\text { management behaviors }\end{array}$} & \multirow{2}{*}{$\begin{array}{l}\text { The Brief Pain } \\
\text { Inventory (BPI)- } \\
\text { Short Form19 } \\
\text { The Patient- } \\
\text { reported } \\
\text { Outcomes } \\
\text { Measurement } \\
\text { Information } \\
\text { System (PROMIS) } \\
\text { The Pain } \\
\text { Catastrophizing } \\
\text { Scale (PCS)1 }\end{array}$} & \multirow{2}{*}{$\begin{array}{l}\text {-presence of chronic } \\
\text { pain was self-reported } \\
\text { and medical diagnoses } \\
\text { were not confirmed. } \\
\text {-demographics for both } \\
\text { studies revealed that } \\
\text { both } \\
\text { samples were } \\
\text { predominantly female } \\
\text { and middle aged. } \\
\text {-phase I predominantly } \\
\text { Caucasian and college } \\
\text { educated }\end{array}$} & \multirow[t]{2}{*}{$\begin{array}{l}\text { Level I } \\
\text { A }\end{array}$} \\
\hline & & & $\begin{array}{l}\text { Chronic care } \\
\text { Pts } \\
\text { validation of } \\
\text { the } \\
\text { CARE scale } \\
\text { was } \\
\text { performed in } \\
\text { a tertiary pain } \\
\text { clinic }\end{array}$ & & & & \\
\hline
\end{tabular}

Note. HER, electronic health records; MEDD, morphine equivalent daily dose; LTOT, long term opioid therapy; Nalox, naloxone education/prescription; PC-POP, Primary Care Pain Education and Opioid Monitoring Program; PDMP, prescription drug monitoring program; PTS, patients; UDS, urine drug screen; VA/DoD, Veterans Affairs/Department of Defense 


\section{Appendix B}

\section{Systematic Review}

\begin{tabular}{|c|c|c|c|c|c|c|c|}
\hline & & & $\begin{array}{l}\text { PICOT EBF } \\
\text { In adult pati } \\
\text { implementa } \\
\text { improve hec }\end{array}$ & $\begin{array}{l}\text { QUESTION: } \\
\text { ats at an outpatient ch } \\
\text { on of a safe opioid ris } \\
\text { h literacy and self-ca }\end{array}$ & $\begin{array}{l}\text { onic pain manage } \\
\text {-reduction strateg } \\
\text { behaviors }(\mathrm{O}) \mathrm{O}\end{array}$ & $\begin{array}{l}\text { ent clinic (P), how does developn } \\
\text { toolkit (I), compared to usual pra } \\
\text { r eight weeks (T) }\end{array}$ & $\begin{array}{l}\text { nt and } \\
\text { ce }(\mathrm{C}) \text {, }\end{array}$ \\
\hline \multirow{2}{*}{$\begin{array}{l}\text { Articl } \\
\text { e } \\
\text { Numb } \\
\text { er }\end{array}$} & \multirow[t]{2}{*}{$\begin{array}{l}\text { Author and } \\
\text { Date } \\
\text { Published }\end{array}$} & \multirow[t]{2}{*}{$\begin{array}{l}\text { Evidence } \\
\text { Type }\end{array}$} & $\begin{array}{l}\text { Sample } \\
\text { Size }\end{array}$ & \multirow[t]{2}{*}{$\begin{array}{l}\text { Findings Related } \\
\text { to PICOT } \\
\text { Question }\end{array}$} & \multirow[t]{2}{*}{ Measures } & \multirow[t]{2}{*}{ Limitations } & \multirow[t]{2}{*}{$\begin{array}{l}\text { Evidence } \\
\text { Level } \\
\text { Quality }\end{array}$} \\
\hline & & & Setting & & & & \\
\hline \multirow[b]{2}{*}{1.} & \multirow[t]{2}{*}{$\begin{array}{l}\text { Kadakia, N. } \\
\text { N., et al. } \\
(2020) \text {. }\end{array}$} & \multirow{2}{*}{$\begin{array}{l}\text { Qualitative } \\
\text { Synthesis } \\
\text { Systematic } \\
\text { Review }\end{array}$} & 10 articles & \multirow{2}{*}{$\begin{array}{l}\text { 1. the results do not } \\
\text { support one method } \\
\text { of pt education as } \\
\text { being superior to } \\
\text { another. } \\
2 \text {. Two studies } \\
\text { measured } \\
\text { knowledge of } \\
\text { medication as a } \\
\text { primary outcome. } \\
\text { 3. Statistical } \\
\text { significance shown } \\
\text { for improvements } \\
\text { in knowledge }\end{array}$} & \multirow{2}{*}{$\begin{array}{l}\text { Pain self- } \\
\text { efficacy } \\
\text { Questionnaire } \\
\text { Prescription } \\
\text { Opioid } \\
\text { Difficulty Scale }\end{array}$} & \multirow{2}{*}{$\begin{array}{l}\text { - number of included studies } \\
\text { - consistent results and } \\
\text { recommendation } \\
\text { - comprehensive literature } \\
\text { review with reference to } \\
\text { scientific evidence }\end{array}$} & \multirow[t]{2}{*}{$\begin{array}{l}\text { Level III } \\
\text { A }\end{array}$} \\
\hline & & & $\begin{array}{l}\text { Varied } \\
\text { ED, pain } \\
\text { clinic, } \\
\text { primary } \\
\text { care, level } \\
1 \text { trauma } \\
\text { center, } \\
\text { medical } \\
\text { center }\end{array}$ & & & & \\
\hline \multirow{2}{*}{2.} & \multirow[t]{2}{*}{$\begin{array}{l}\text { Wang, C., et } \\
\text { al. (2020). }\end{array}$} & \multirow[t]{2}{*}{$\begin{array}{l}\text { Quantitative } \\
\text { Synthesis } \\
\text { Systematic } \\
\text { Review }\end{array}$} & 26 articles & \multirow{2}{*}{$\begin{array}{l}\text { 1. Micro learning } \\
\text { interventions using } \\
\text { short videos were } \\
\text { most popular. } \\
\text { 2. Studies showed } \\
\text { statistically } \\
\text { significant positive } \\
\text { effect of } \\
\text { microlearning on }\end{array}$} & \multirow{2}{*}{$\begin{array}{l}\text { Self-care } \\
\text { behavioral } \\
\text { changes } \\
\text { Health literacy } \\
\text { score } \\
\text { Wellness score } \\
\text { Healthy } \\
\text { behavior } \\
\text { change. }\end{array}$} & \multirow{2}{*}{$\begin{array}{l}\text {-one teen study } \\
\text {-only } 4 \text { studies contained equal } \\
\text { distribution between gender } \\
\text { groups } \\
\text { - learning was focused on } \\
\text { varied chronic health conditions } \\
\text {-not all US studies } \\
\text {-some studies with high to mod } \\
\text { bias risks }\end{array}$} & \multirow[t]{2}{*}{$\begin{array}{l}\text { Level II } \\
\text { B }\end{array}$} \\
\hline & & & $\begin{array}{l}\text { Varied } \\
\text { Clinical, } \\
\text { university, } \\
\text { community }\end{array}$ & & & & \\
\hline
\end{tabular}




\begin{tabular}{|l|l|l|l|l|l|l|}
\hline & & $\begin{array}{l}\text { and } \\
\text { department } \\
\text { of } \\
\text { corrections }\end{array}$ & $\begin{array}{l}\text { improved } \\
\text { knowledge and } \\
\text { health literacy } \\
\text { behaviors }\end{array}$ & $\begin{array}{l}\text { Treatment } \\
\text { adherence } \\
\text { Health product } \\
\text { use and misuse }\end{array}$ & \\
\hline
\end{tabular}

Note. Pt., patient. 


\section{Appendix C}

\section{Consensus Statement/Guidelines}

\begin{tabular}{|c|c|c|c|c|c|c|c|}
\hline \multirow{3}{*}{$\begin{array}{l}\text { Articl } \\
\text { e } \\
\text { Numb } \\
\text { er }\end{array}$} & \multirow{3}{*}{$\begin{array}{l}\text { Author and } \\
\text { Date } \\
\text { Published }\end{array}$} & \multirow{3}{*}{$\begin{array}{l}\text { Evidence } \\
\text { Type }\end{array}$} & \multicolumn{5}{|c|}{$\begin{array}{l}\text { PICOT EBP QUESTION: } \\
\text { In adult patients at an outpatient chronic pain management clinic (P), how does development and } \\
\text { implementation of a safe opioid risk-reduction strategy toolkit }(\mathrm{I}) \text {, compared to usual practice }(\mathrm{C}) \text {, } \\
\text { improve health literacy and self-care behaviors }(\mathrm{O}) \text { over eight weeks }(\mathrm{T})\end{array}$} \\
\hline & & & $\begin{array}{l}\text { Sample } \\
\text { Size } \\
\text { Setting }\end{array}$ & $\begin{array}{l}\text { Findings Related to } \\
\text { PICOT Question }\end{array}$ & Measures & Limitations & $\begin{array}{l}\text { Evidence } \\
\text { Level } \\
\text { Ouality }\end{array}$ \\
\hline & & & & & & & \\
\hline \multirow[t]{2}{*}{1.} & \multirow[t]{2}{*}{$\begin{array}{l}\text { Dowell, D., } \\
\text { et al. (2016). }\end{array}$} & \multirow[t]{2}{*}{$\begin{array}{l}\text { Center for } \\
\text { Disease } \\
\text { Control } \\
\text { and } \\
\text { Prevention } \\
\text { Guidelines }\end{array}$} & N/A & \multirow{2}{*}{$\begin{array}{l}\text { 1. Supports nalox and } \\
\text { education as a critical } \\
\text { component to stopping } \\
\text { OOD } \\
\text { 2. Resources for tool kit } \\
\text { including clinician and pt } \\
\text { education. } \\
\text { 3.Includes safe disposal } \\
\text { and usage education }\end{array}$} & \multirow[t]{2}{*}{ N/A } & \multirow[t]{2}{*}{ N/A } & \multirow[t]{2}{*}{$\begin{array}{l}\text { Level IV } \\
\text { A }\end{array}$} \\
\hline & & & U.S. & & & & \\
\hline \multirow[b]{2}{*}{2.} & \multirow[t]{2}{*}{$\begin{array}{l}\text { Ducoffe, A. } \\
\text { R., et al. } \\
(2016) \text {. }\end{array}$} & \multirow{2}{*}{$\begin{array}{l}\text { Office of } \\
\text { Disease } \\
\text { Prevention } \\
\text { and Health } \\
\text { Promotion } \\
\text { The } \\
\text { National } \\
\text { Action } \\
\text { Plan for } \\
\text { Adverse } \\
\text { Drug Event } \\
\text { Prevention }\end{array}$} & N/A & \multirow{2}{*}{$\begin{array}{l}\text { 1. Supports nalox and } \\
\text { education as a critical } \\
\text { component to stopping } \\
\text { OOD. } \\
\text { 2. Resources for tool kit } \\
\text { including clinician and pt } \\
\text { education. } \\
\text { 3.Includes safe disposal } \\
\text { and usage education }\end{array}$} & \multirow[t]{2}{*}{ N/A } & \multirow[t]{2}{*}{$\begin{array}{l}\text {-original report includes } \\
\text { recommendations for } \\
\text { anticoagulants, and diabetes } \\
\text { agents }\end{array}$} & \multirow[t]{2}{*}{$\begin{array}{l}\text { Level IV } \\
\text { A }\end{array}$} \\
\hline & & & Outpatient & & & & \\
\hline
\end{tabular}




\begin{tabular}{|c|c|c|c|c|c|c|c|}
\hline 3. & $\begin{array}{l}\text { U.S. } \\
\text { Department } \\
\text { of Health \& } \\
\text { Human } \\
\text { Services. } \\
\text { (2019). }\end{array}$ & $\begin{array}{l}\text { U.S. } \\
\text { Department } \\
\text { of Health } \\
\text { \& Human } \\
\text { Service } \\
\text { inter- } \\
\text { agency task } \\
\text { force } \\
\text { Best } \\
\text { practices }\end{array}$ & U.S. & $\begin{array}{l}\text { 1. Supports nalox and } \\
\text { education as a critical } \\
\text { component to stopping } \\
\text { OOD. } \\
\text { 2. Resources for tool kit } \\
\text { including clinician and pt } \\
\text { education. } \\
\text { 3.Includes safe disposal } \\
\text { and usage education }\end{array}$ & N/A & N/A & $\begin{array}{l}\text { Level IV } \\
\text { A }\end{array}$ \\
\hline 4. & $\begin{array}{l}\text { U.S. } \\
\text { Department } \\
\text { of Health \& } \\
\text { Human } \\
\text { Services. } \\
\text { (2018). }\end{array}$ & $\begin{array}{l}\text { US } \\
\text { Surgeons } \\
\text { General } \\
\text { Advisory } \\
\text { Statement }\end{array}$ & N/A & $\begin{array}{l}\text { 1. Supports nalox and } \\
\text { education as a critical } \\
\text { component to stopping } \\
\text { OOD. } \\
\text { 2. Resources for tool kit } \\
\text { including clinician and pt } \\
\text { education. }\end{array}$ & N/A & $\begin{array}{l}\text { Mainly addresses nalox } \\
\text { information }\end{array}$ & $\begin{array}{l}\text { Level V } \\
\text { A }\end{array}$ \\
\hline
\end{tabular}

Note: nalox, naloxone prescription; OOD, opioid overdose 


\section{SWOT Analysis}

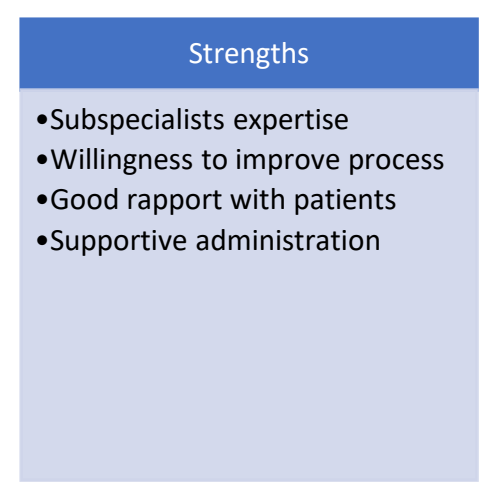

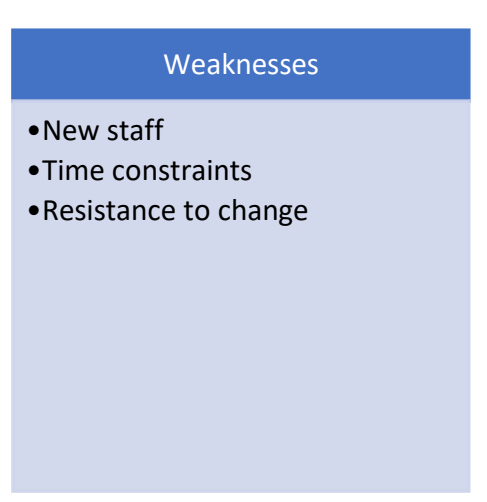

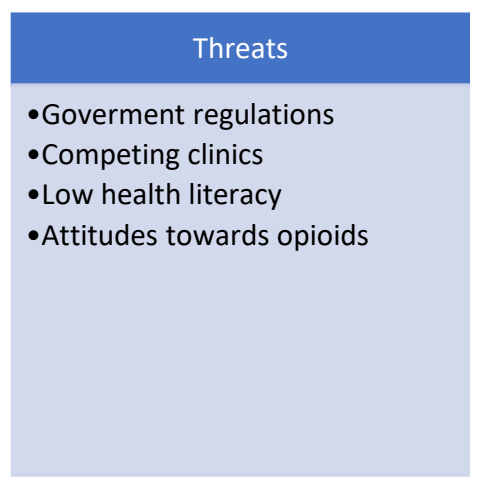




\section{Appendix E}

\section{Provider Teach-Back Method Video}

https://youtu.be/bzpJJYF_tKY

Note. Obtained from IHI Open School, Available through open access, no changes made.

\section{Provider Naloxone Handout}

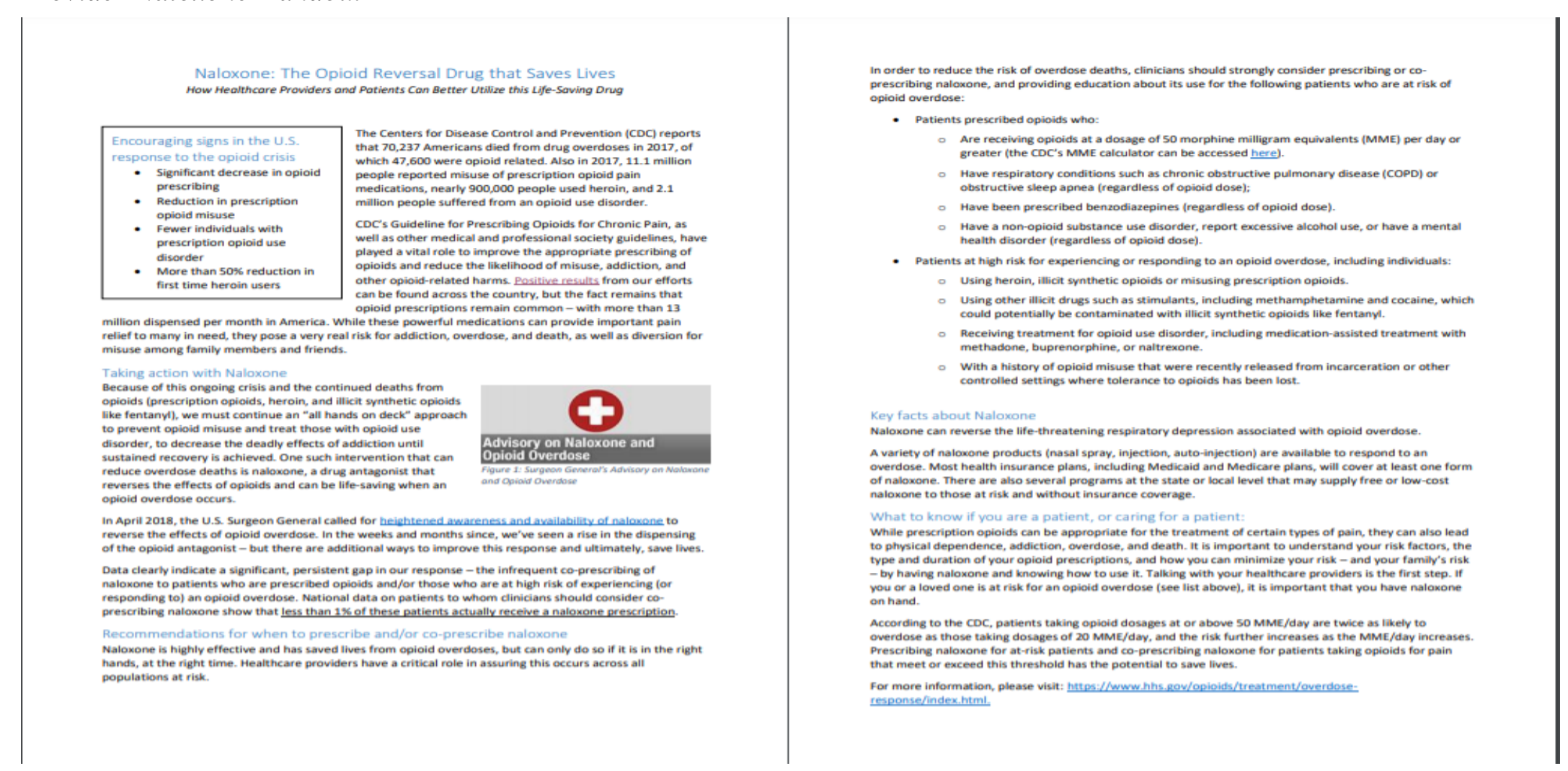

Note. From HHS.Gov (https://www.hhs.gov/opioids/sites/default/files/2018-12/naloxone-coprescribing-guidance.pdf). In the public domain. 


\section{Appendix F}

\section{Handouts}

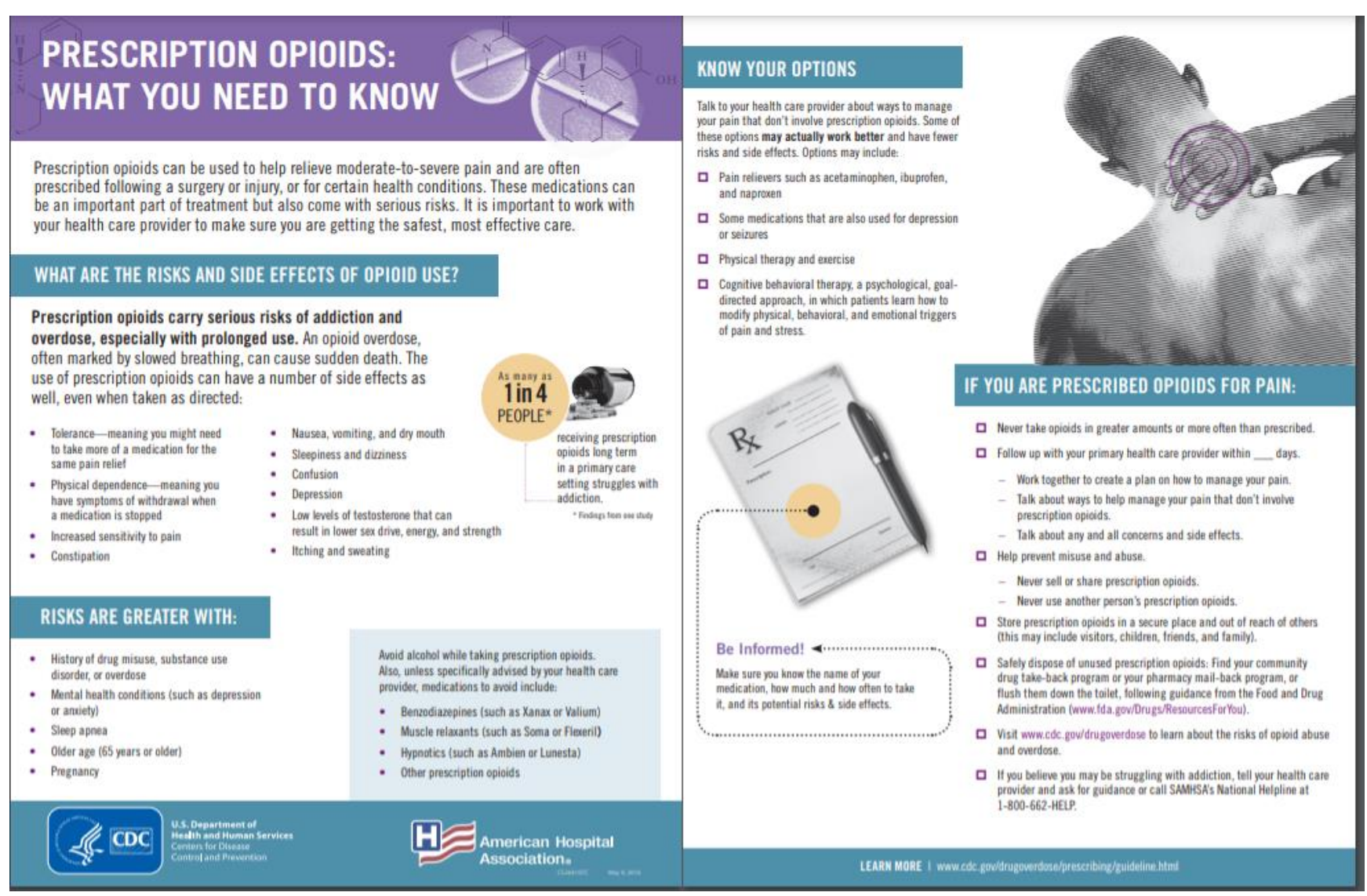

Note. From the CDC Prescription Opioids: What You Need to Know, no changes made.

(https://www.cdc.gov/drugoverdose/pdf/aha-patient-opioid-factsheet-a.pdf). In the public domain. 

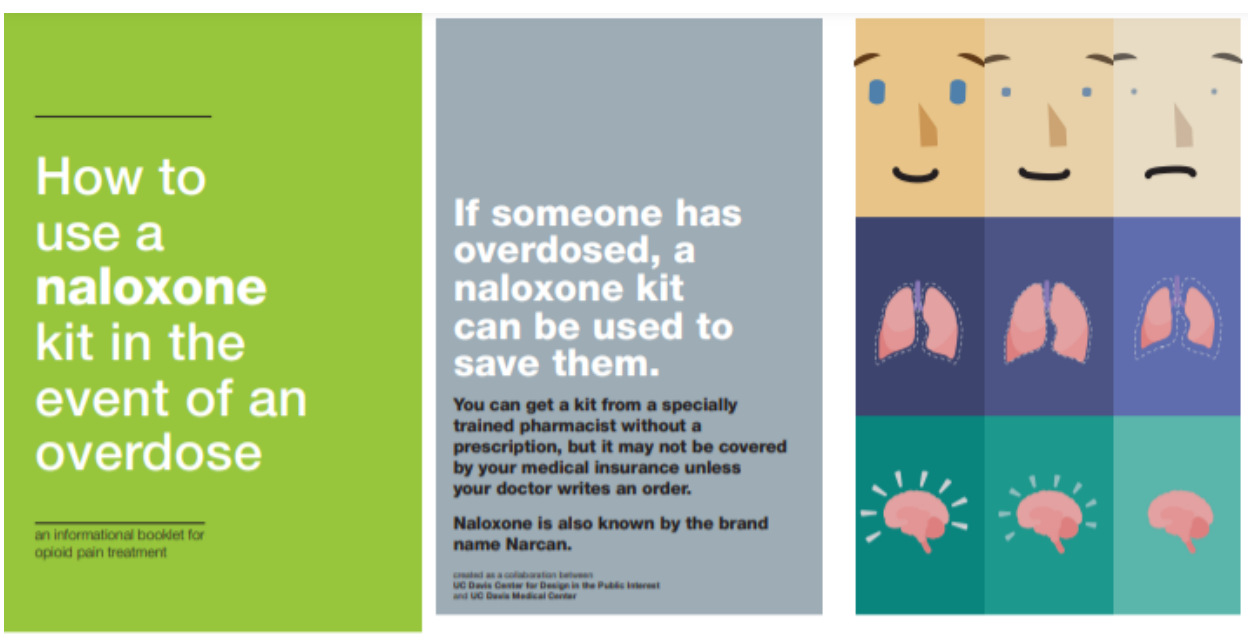

\section{Can naloxone} be harmful?

\section{Serious side effects of} naloxone are very rare. The most common side effect is opioid etfect of opioids. Common opioid withdraw symptoms include aches, iritabiely, sweating. It's most important to give someone nabxone if you think they are experiencing an overdose
because it can save them from brain damage or even death.

\section{How do I know} when to use naloxone?

If you think someone is experiencing an opioid to give naloxone.

Naloxone reverses the effects of opioids such mornhine, opum, the effects of other types of drugs like alcono or stimulants Iske cocaine it the person has person will likely start breathing but continui
How can I tell if it's working?

If someone is experiencing given naloxone, they should wake up in 2-3 minutes.

It the person does not wake up in 3 minutes
or beses consciusueneass again atter $30-90$ or boses conscibusness again after $30-90$
minutes, give them a second dose of naloxone. Stay with the person until help arrives.
What does

an overdose

look like?

\section{Learn the signs of a opicid overdose}

\section{Three strong signs}

of overdose are:

-tiny, pinpoint pupils

-slow and shallow

breathing

-unconsciousness

and /or unresponsiveness

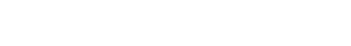

What do I need to do?

\begin{tabular}{ll}
1 Try to wake the person up \\
\hline 2 Give the first dose of naloxone \\
\hline 3 Call 911 \\
\hline 4 Check for breathing \\
\hline $5 \begin{array}{c}\text { Be prepared to give a second dose of } \\
\text { naloxone if needed }\end{array}$ \\
\hline
\end{tabular}




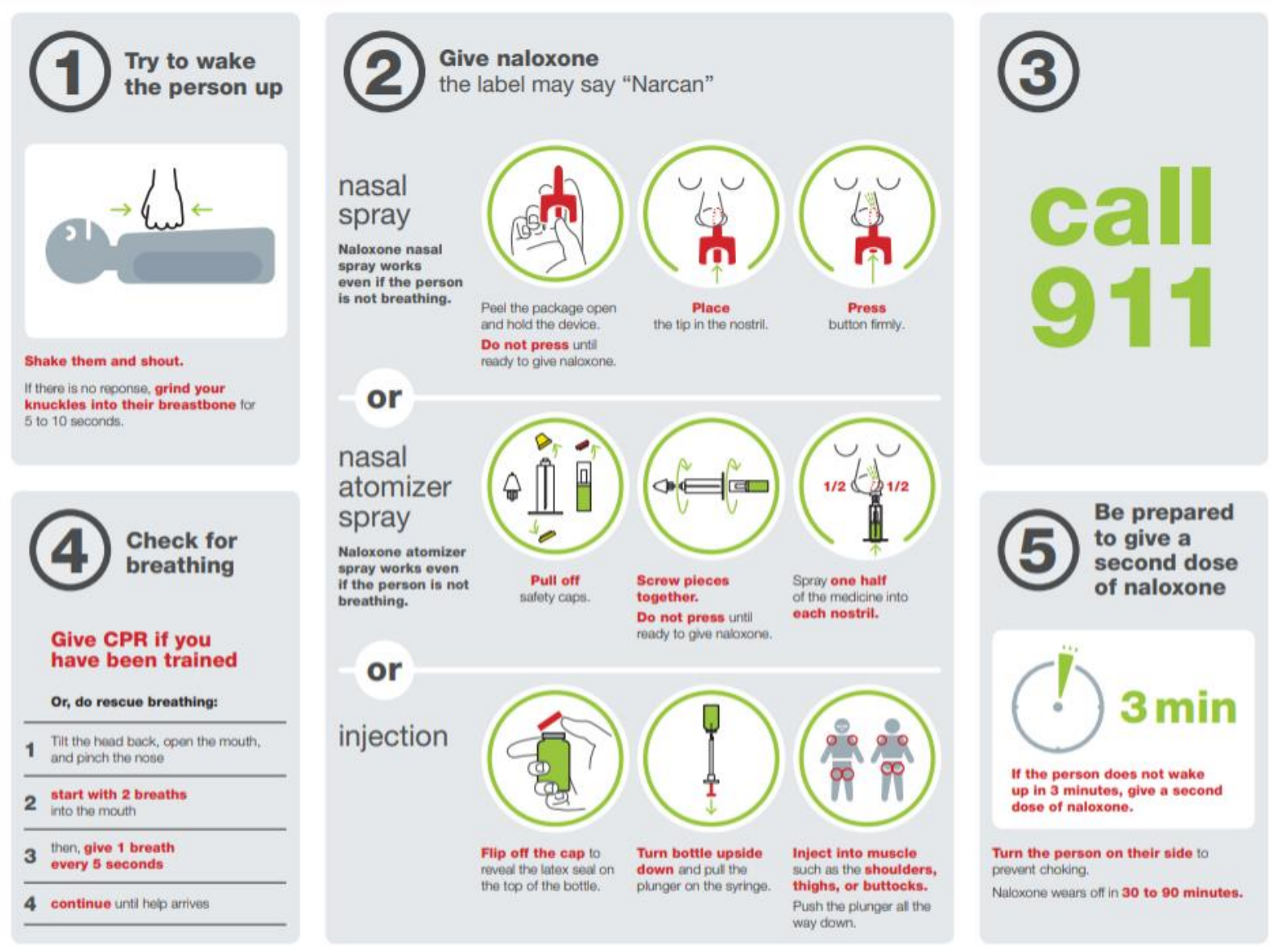

Note. From "How to Use a Naloxone Kit in the Event of an Overdose," by UC Davis Center for Design and UC Davis Medical Center, 2020. (https://naloxonesaves.org/wp-content/uploads/sites/19608/2020/02/How-to-Use-Naloxone-Brochure-ALL-formulations2.pdf). CC BY NC-

ND 4.0. 


\section{Appendix G}

\section{Provider Information}

First OV

"Please read these two handouts before your next visit so we can talk about the information on safer opioid use and go over any questions you have. We want to be sure every patient understands the risks to opioid use. We want you and your family to be as safe as possible." (checkbox)

"I am going to prescribe Narcan for you today. It is very important that anyone who has opioids in the home have this in case of an emergency. It is like a fire-extinguisher- no one plans on using it but are glad they have one if needed. Will your insurance pay for this, or do you want to have it shipped to you?

If they already have RX- "please check the expiration date and let us know when it needs to be refilled or if you felt you would benefit from having an extra one to carry with you I can prescribe that too."

"Do you feel very comfortable giving someone Narcan and when to use it?" (checkbox)

"There is information on when and how to give Narcan and we can talk about any questions when you come back."

\section{Second OV}

"I know I gave you 2 papers to read last month. To make sure that I am giving you all the information that you need what can we talk about so that you are comfortable with how to take and store your medication? Do you know where you would dispose of your medications if you do not need them anymore?" (checkbox)

"Do you have Narcan available to you?" Check PDMP and EMR for Narcan filled since the last OV (checkbox)

If no RX- "I really want to make sure that you have this reversal medication so that you are safe. What can I do so that we can get it to you?"

"Can you explain to me your understanding of how and when you would give someone Narcan?" (checkbox) 
Appendix H

Office Posters

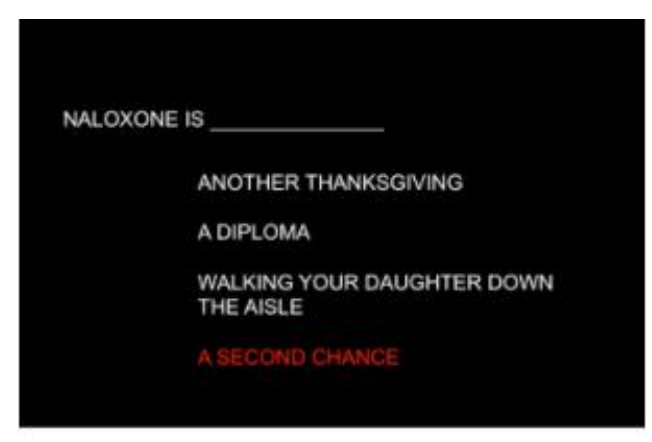

Drug overdose ranks as the leading cause of adult accidental death in the U.S. With naloxone you have

Avaliable without a prescription.

Talk to your pharmacist about naloxone.

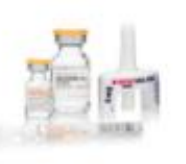

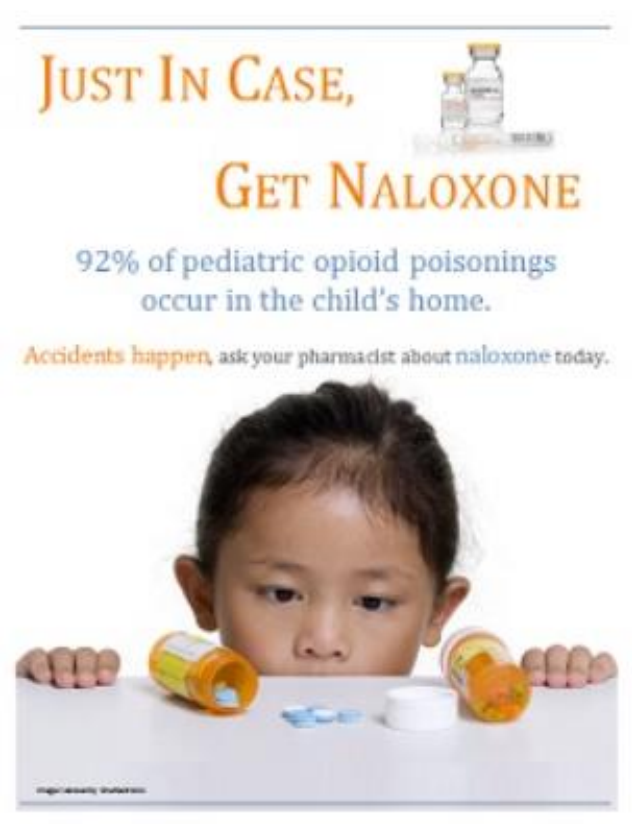

Naloxone Naloxone Naloxone Naloxone Naloxone life.

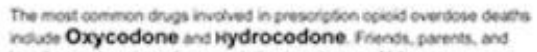

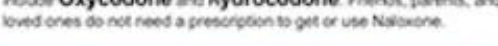
Using Naloxone can stop an opioid overdose. One lfe. Save in with Natoxone. Ask a Pharmacist. 

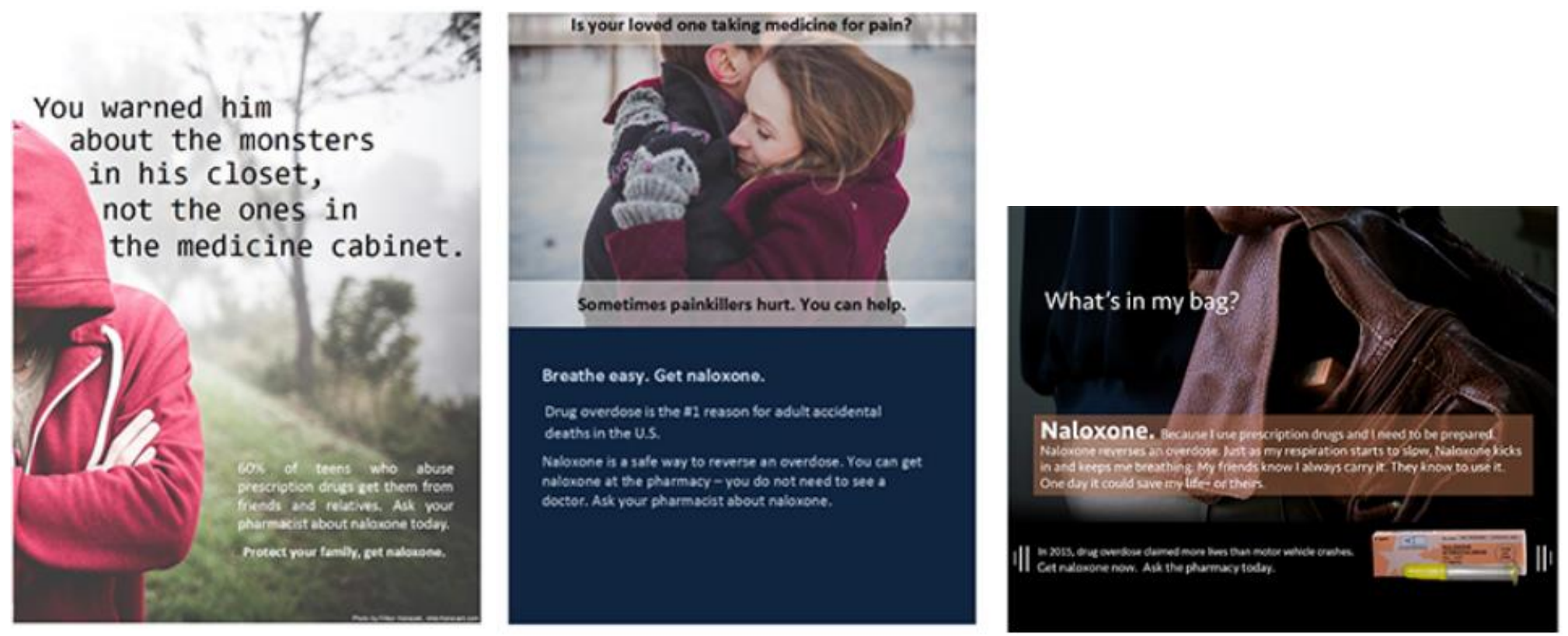

Note. Posters from "Prevent and Protect"- site by: web360 (https://prevent-protect.org/). Copyright @ 2021- Customizable posters with a blank permission to use and adapt any material on the site, in the public domain. 


\section{Appendix I}

Provider Checklist

\begin{tabular}{|c|c|c|c|c|}
\hline \multicolumn{3}{|c|}{ OFFICE VISIT \#1 } & \multicolumn{2}{|c|}{ DATE: } \\
\hline \multicolumn{5}{|l|}{ Provider initials- } \\
\hline & YES & NO & N/A & Comments: \\
\hline \multicolumn{5}{|l|}{$\begin{array}{l}\text { The patient } \\
\text { was given the } \\
\text { two project } \\
\text { handouts. }\end{array}$} \\
\hline \multicolumn{5}{|l|}{$\begin{array}{l}\text { The patient } \\
\text { was offered a } \\
\text { Narcan RX. }\end{array}$} \\
\hline $\begin{array}{l}\text { The patient } \\
\text { has previously } \\
\text { received } \\
\text { Narcan from a } \\
\text { pharmacy } \\
\text { within the last } \\
\text { year. } \\
\text { Verified from } \\
\text { PDMP/EMR. }\end{array}$ & & & & \\
\hline
\end{tabular}




\begin{tabular}{|c|c|c|c|c|}
\hline $\begin{array}{l}\text { The patient is } \\
\text { going to } \\
\text { receive } \\
\text { Narcan from } \\
\text { NEXT distro } \\
\text { and watch the } \\
\text { video. }\end{array}$ & & & & \\
\hline $\begin{array}{l}\text { The patient } \\
\text { can correctly } \\
\text { verbalize how } \\
\text { and when to } \\
\text { use Narcan. }\end{array}$ & & & & \\
\hline OFFICE & VISI & & DAT & \\
\hline Provider initials- & & & & \\
\hline & YES & NO & $\mathrm{N} / \mathrm{A}$ & Comments: \\
\hline $\begin{array}{l}\text { The patient } \\
\text { verbalizes the } \\
\text { safe opioid } \\
\text { use in teach- } \\
\text { back format }\end{array}$ & & & & \\
\hline $\begin{array}{l}\text { The patient } \\
\text { has received } \\
\text { Narcan from a } \\
\text { pharmacy. } \\
\text { Verified from } \\
\text { PDMP/EMR }\end{array}$ & & & & \\
\hline
\end{tabular}




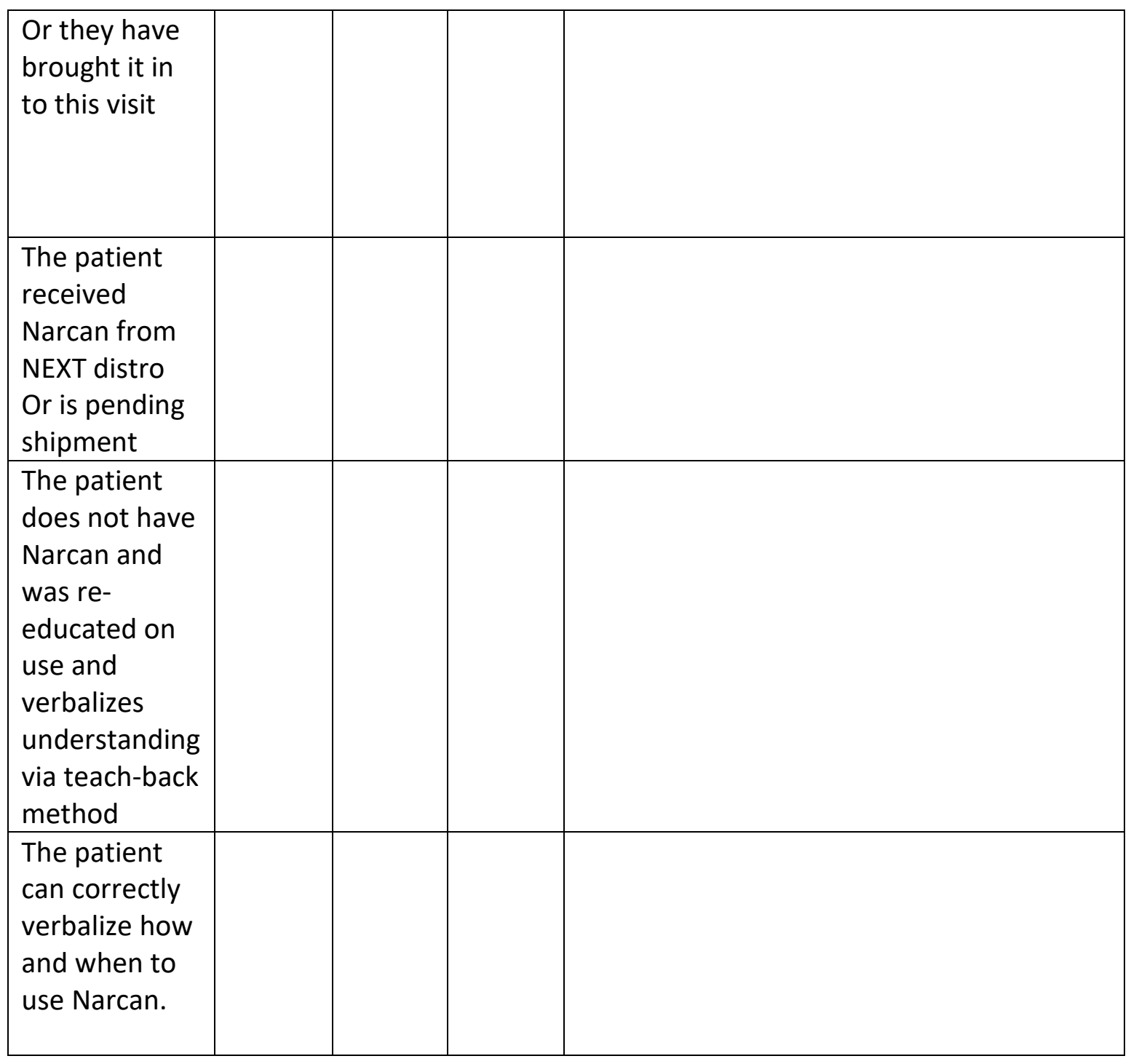




\section{Appendix J}

Timeline Chart

Project Title: Development and Implementation of a Safe Opioid Risk-Reduction Office Policy

Project Description: An EBP Change Project to Improve Health Literacy and the Safe Use of Opioids at an Outpatient Pain Clinic Project Lead: Heather Darmetko MSN, FNP Team Members: Dr. Rao CMO, Christina Marshall CNO, Greg Hites DNP, TBD MA, TBD Office Manager, TBD NP, MP IT

Project start

date:

Mon, $1 / 11 / 2021$

Project End Date:

$12 / 14 / 2021$

\begin{tabular}{|c|c|c|c|}
\hline TASK & $\begin{array}{c}\text { ASSIGNED } \\
\text { TO }\end{array}$ & START & END \\
\hline Literature Review & Project Manager H.D. & $1 / 11 / 21$ & $1 / 24 / 21$ \\
\hline SWOT Org. Analysis & Project Manager H.D. & $1 / 14 / 21$ & $1 / 21 / 21$ \\
\hline Stakeholder Determination & Project Manager H.D. & $1 / 16 / 21$ & $1 / 18 / 21$ \\
\hline PICOT Statement & Project Manager H.D. & $1 / 18 / 21$ & $1 / 24 / 21$ \\
\hline Identify Project Champions & Project Manager H.D, DNP G.H. & $2 / 14 / 21$ & $2 / 18 / 21$ \\
\hline Protocol Development & Project Manager H.D. & $2 / 28 / 21$ & $3 / 21 / 21$ \\
\hline Preceptor Approval & Project Manager H.D. & $3 / 11 / 21$ & $4 / 11 / 21$ \\
\hline Submit Project Proposal & Project Manager H.D. & $1 / 10 / 21$ & $4 / 4 / 21$ \\
\hline
\end{tabular}




\begin{tabular}{|c|c|c|c|}
\hline EPRC Submission & USA Faculty & $5 / 16 / 21$ & $5 / 23 / 21$ \\
\hline IRB Approval & Project Manager H.D. & $5 / 23 / 21$ & $5 / 25 / 21$ \\
\hline Approved Project Org. Submission & CMO Dr. R & $5 / 24 / 21$ & $5 / 27 / 21$ \\
\hline Budget Approval & CNO C.M. & $5 / 24 / 21$ & $5 / 27 / 21$ \\
\hline Final Process Flowchart & Office Manager, Lead MA & $5 / 30 / 21$ & $5 / 31 / 21$ \\
\hline Finalize EHR for Project & Lead IT & $5 / 30 / 21$ & $6 / 3 / 21$ \\
\hline Collect Baseline Data & Project Manager H.D. & $5 / 30 / 21$ & $6 / 7 / 21$ \\
\hline Office Protocol Review & CNO C.M. & $5 / 30 / 21$ & $5 / 31 / 21$ \\
\hline Provider Presentation & Project Manager H.D. & $6 / 2 / 21$ & $6 / 2 / 21$ \\
\hline Lunch and Learn Office Presentation & Project Manager H.D. & $6 / 4 / 21$ & $6 / 4 / 21$ \\
\hline Staff Email & Project Manager H.D. & $6 / 7 / 21$ & $6 / 7 / 21$ \\
\hline Patient Enrollment & Office Manager & $6 / 7 / 21$ & $6 / 18 / 21$ \\
\hline Collect Project Patient Data & Project Manager H.D. & $6 / 12 / 21$ & $6 / 13 / 21$ \\
\hline Collect Project Patient Data & Project Manager H.D. & $6 / 19 / 21$ & $6 / 20 / 21$ \\
\hline Staff Process Review & Provider GH & $6 / 8 / 21$ & $6 / 8 / 21$ \\
\hline
\end{tabular}




\begin{tabular}{|c|c|c|c|}
\hline Handout Process Review and Revision PRN & Lead MA Office Mgr. DNP & $6 / 8 / 21$ & $6 / 9 / 2021$ \\
\hline Staff Email & Project Manager H.D. & $6 / 20 / 21$ & $6 / 20 / 21$ \\
\hline Board members Email & Project Manager H.D. & $6 / 27 / 21$ & $6 / 27 / 21$ \\
\hline Post Patient Survey \#2 & Project Manager H.D. & $7 / 4 / 21$ & $7 / 17 / 21$ \\
\hline Collect EHR Measures 8 weeks & Project Manager H.D. & $7 / 18 / 21$ & $8 / 1 / 21$ \\
\hline Provider Debriefing & Providers & $7 / 14 / 21$ & $7 / 14 / 21$ \\
\hline Staff/Board members Email & Project Manager H.D. & $7 / 18 / 21$ & $7 / 18 / 21$ \\
\hline 60-day Review Meeting & $\begin{array}{l}\text { CMO Dr. R CNO C.M. Project Manager } \\
\text { H.D. }\end{array}$ & $9 / 13 / 21$ & $9 / 13 / 2021$ \\
\hline Finalize data collection & Project Manager H.D. & $9 / 13 / 21$ & $9 / 17 / 21$ \\
\hline Evaluate Outcome Measures to Create Project Findings & Project Manager H.D. & $9 / 17 / 21$ & 9/27/21 \\
\hline Submit final project manuscript to primary faculty & USA, Project Manager H.D. & $11 / 22 / 21$ & $11 / 28 / 21$ \\
\hline Publish Findings-submit final approved project manuscript to SOAR & Project Manager H.D. & $11 / 22 / 21$ & $11 / 28 / 21$ \\
\hline Disseminate Findings & Dr. Rao, CM, GH, Project Manager H.D. & $11 / 29 / 21$ & $11 / 29 / 21$ \\
\hline Completion/Thank you Email & Project Manager H.D. & $12 / 3 / 21$ & $12 / 3 / 21$ \\
\hline
\end{tabular}




\section{Appendix K}

Evaluation Plan for: Development and Implementation of a Safe Opioid Risk-Reduction Strategy Toolkit Project Design: pre and post design Heather Darmetko MSN, APRN, FNP

This is an evidenced based practice project to improve patient outcomes at an interventional outpatient pain clinic. The purpose is to increase patient and provider knowledge on safe use of prescription opioids by development and implementation of an office policy.

\begin{tabular}{|c|c|c|c|c|c|c|c|c|c|c|c|c|c|c|c|c|}
\hline \multirow[t]{2}{*}{ MEASURES } & \multicolumn{4}{|c|}{ CATEGORIES } & \multicolumn{4}{|c|}{ TIME for DATA COLLECTION } & \multicolumn{5}{|c|}{ STATISTICAL TEST } & \multirow{2}{*}{$\begin{array}{l}\text { BASELINE } \\
\text { Values }\end{array}$} & \multicolumn{2}{|c|}{ GOAL } \\
\hline & OUTCOME & PROCESS & BALANCING & FINANCIAL SUSTAINABELITY & Baseline & 1 week & 2 weeks & 4 weeks & $\begin{array}{c}\text { Data } \\
\text { Description }\end{array}$ & $\begin{array}{c}\text { paired t- } \\
\text { test }\end{array}$ & $\begin{array}{c}\text { unpaired } t \text { - } \\
\text { test }\end{array}$ & $x^{2}$ & Other & & 4 weeks & 8 weeks \\
\hline $\begin{array}{l}\text { Average 1. The rate } \\
\text { of prescribing } \\
\text { provider adherence } \\
\text { will be measured with } \\
\text { a percentage change } \\
\text { of before and after } \\
\text { project } \\
\text { implementation-data } \\
\text { is collected by the } \\
\text { PDMP. Average is } \\
\text { obtained by adding } \\
\text { the total score } \\
\text { amount from each } \\
\text { patient and dividing } \\
\text { by the number of } \\
\text { patients. }\end{array}$ & $\mathrm{x}$ & & & & $\mathrm{x}$ & & & $\mathbf{x}$ & Nominal & & $\mathrm{x}$ & & & & & $\geq 95 \%$ \\
\hline
\end{tabular}




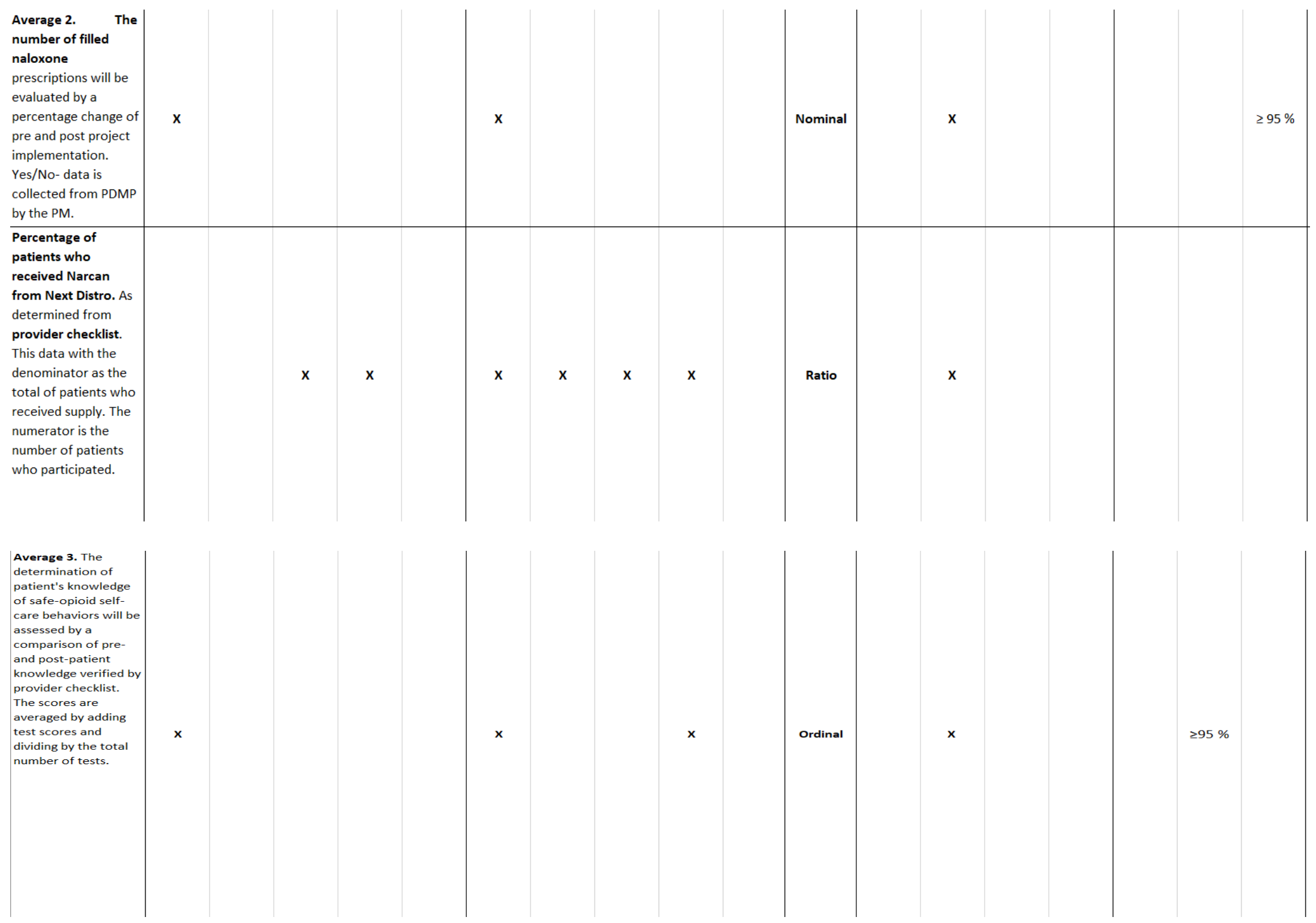




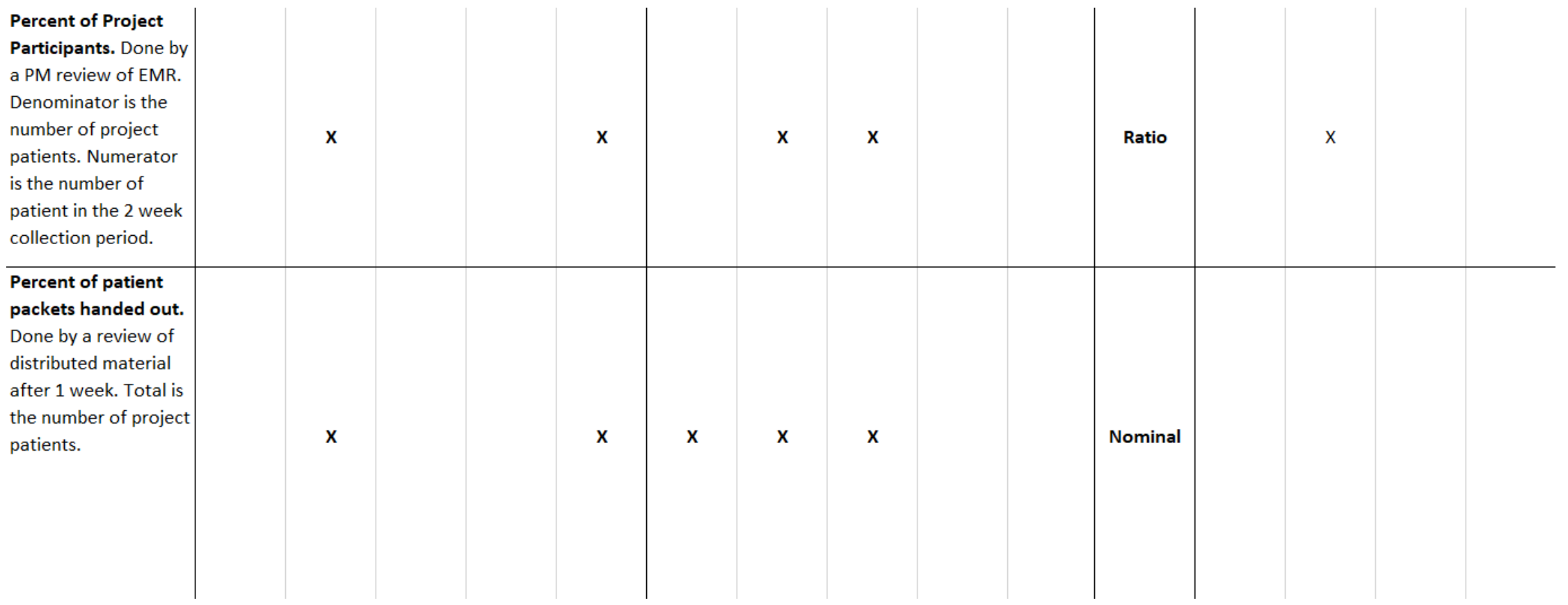

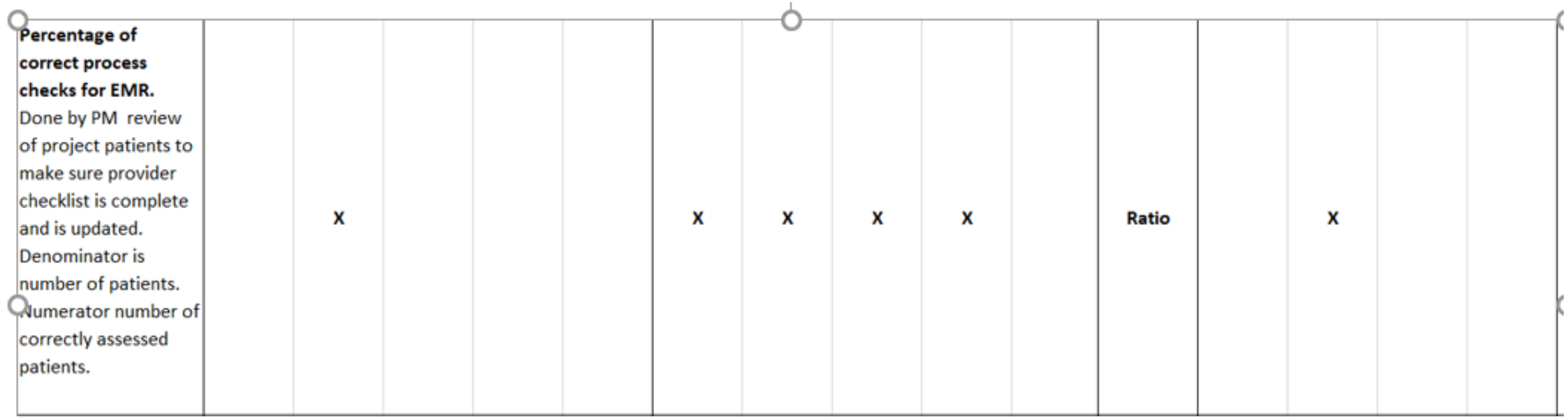

